\title{
30. COMPOSITION, PROVENANCE, AND DIAGENESIS OF CRETACEOUS CLASTIC SEDIMENTS DRILLED ON THE ATLANTIC CONTINENTAL RISE OFF SOUTHERN AFRICA, DSDP SITE 361 - IMPLICATIONS FOR THE EARLY CIRCULATION OF THE SOUTH ATLANTIC
}

\author{
James H. Natland, Scripps Institution of Oceanography, La Jolla, California
}

\begin{abstract}
Units 6 and 7 of DSDP Site 361 in the southern Cape Basin consist of over 900 meters of Cretaceous clastic sediments. These record changes in the physical conditions of southern African continental margin sedimentation, and in the chemical and physical oceanography of the South Atlantic Ocean from a time shortly after the separation of South America from Africa until deep marine conditions prevailed in a much wider Late Cretaceous ocean basin. This chapter summarizes evidence that Unit 7 was deposited in an anoxic, at times nearly stagnant water mass, and that Unit 6 represents the onset both of oxygenating bottom conditions and vigorous bottom currents. Unit 7 consists of coarse turbidites and debris-flow sandstones, sandy mudstones, and shales, whereas Unit 6 is well-sorted finely cross-laminated siltstones and shales. Both a decline in the relief of source regions (primarily by subsidence in response to lithospheric cooling following continental rifting) and the onset of currents are responsible for the lithologic changes.

$\mathrm{X}$-ray fluorescence and atomic absorption chemical analyses of sediments show that Cape granites and associated metomorphic rocks are the predominant source of Unit 7 , whereas a significantly more mafic source is required for some Unit 6 shales and siltstones. This represents a shift from an extremely local provenance to one with input from more northerly sources such as the Orange River which drains basaltic and andesitic terranes in the Karroo Basin and Namaqualand. Transition trace metals in Unit 7 sandstones, however, are higher than in any of their potential source rocks, and apparently have been added to the sediments by chelation and other biological processes affecting or resulting in organic material and pyrite, both abundant in the sediments. Analyzed red shales interbedded with Unit 6 siltstones differ from pelagic clays of the latest Cretaceous (?)-Paleocene Unit 5 of Site 361 in having low $\mathrm{MnO}$ and few or no ichthyoliths (fish debris). They are thus inferred to have a terrigenous source.
\end{abstract}

Scanning Electron Microscope photographs and X-ray diffraction mineralogical data are used to discuss the diagenesis of Unit 7 sandstones in the unusual anoxic environment in which they were deposited. An unusually saline bottom water composition appears required to explain the authigenic mineral assemblage kaolinite-illite-phillipsite. The same authigenic mineral assemblage occurs in carbonaceous shales cored above the evaporites in the Angola Basin at Site 364. In Unit 7 of Site 361, in situ dissolution of calcium carbonate appears to have been driven by the necessity to maintain pore fluid alkalinity as hydroxyl, $\mathrm{Ca}, \mathrm{K}, \mathrm{Na}$, and other cations entered the authigenic minerals. These minerals, and framboidal pyrite associated with organic material suggest that diagenesis occurred at a $\mathrm{pH}$ of at least 8 and probably more than 9 . Shipboard analyses of Unit 7 sandstone pore waters (Sotelo and Gieskes, this volume) show higher chlorinity and alkalinity than expected, suggesting an evaporite body is deeply buried within the southern African continental margin sediment wedge. This is the only evidence for still an earlier phase of more restricted circulation in the newly opened Cape Basin uncovered on Leg 40.

The physical and chemical factors influencing the provenance, composition, and diagenesis of the sediments are used to formulate a 
model for the developing circulation of the widening South Atlantic during the Cretaceous. A dense, hypersaline mass of anoxic bottom water occupied the Cape Basin during the Aptian when Unit 7 was deposited. The water mass was dammed behind a high sill between Africa and the Falkland Plateau which were close together at the time. Some spillage of dense, saline waters across Walvis Ridge into the Cape Basin from the even more restricted Angola evaporite basin to the north is inferred to explain the authigenic mineral assemblage in Unit 7. An even more voluminous spillage of episodically anoxic dense Angola Basin bottom waters occurred during the deposition of Unit 6, during which time the Cape Basin was generally oxygenated. A southward-flowing eastwardintensified dense bottom current is proposed to explain erosion and sedimentary structures at Site 363 on Walvis Ridge, and in Unit 6 at Site 361 , and to explain the shift to a more northern provenance at Site 361 at that time.

\section{INTRODUCTION}

DSDP Site 361 on the Atlantic continental rise off southern Africa $\left(35^{\circ} 04^{\prime} \mathrm{S}, 15^{\circ} 27^{\prime} \mathrm{E}\right)$ was chosen for drilling on Leg 40 because the sedimentary column was known to include clastic materials derived from southern Africa and deposited in the newly opened South Atlantic Ocean (Figure 1). Evaluation of the early history of continental margin evolution off southern Africa was a major objective of Leg 40 . During the Early Cretaceous, the Falkland Plateau had not yet moved past the tip of southern Africa along the Agulhas Fracture Zone (Francheteau and Le Pichon, 1972; Dingle and Scrutton, 1974). Because these two high-standing continental masses were still close together, a high sill must have separated the South Atlantic from the southern Indian Ocean. This was dramatically confirmed by the deepest cores of Site 361 which penetrated over 300 meters of coarse Aptian sandstones and interbedded black shales, both containing abundant organic carbon fossil plant material including coalified wood chips up to $10 \mathrm{~cm}$ long, and pyrite (see Chapter 2, this volume). Our preliminary conclusion on Leg 40 was that these sediments were deposited in a deep anoxic basin with a dense euxinic water mass dammed behind the sill at the Agulhas Fracture Zone (Bolli, Ryan, et al., 1975). The lowest core of Site 361 is inferred to be only tens of meters above basement, presumed to be oceanic crust based on the presence of magnetic anomalies. Site 361 is located on anomaly M-4, which is about $110 \mathrm{~m} . \mathrm{y}$. old (see Chapter 2, and Larson and Ladd, 1973).

At the same time in the northern portion of the South Atlantic (north of Walvis Ridge) a thick sequence of Aptian evaporites was being deposited (see Franks and Nairn, 1973, for summary). The salt deposits now form a prominent plateau and ridge in the Angola Basin. Our drilling at Site 363 confirmed that Walvis Ridge (see Figure 1) was a high-standing feature at that time, and with the São Paulo Plateau, almost certainly formed a major constriction in the middle of the South Atlantic during the Early Cretaceous (see Chapter 3, this volume). Certainly some major constriction separated the anoxic basin to the south from the evaporite basin to the north.
We thus had recovered evidence for what may have been a unique pair of narrow, linked, and highly restricted basins between separating continents, spanning almost $40^{\circ}$ of latitude and supplied seawater from only the southern end, across a high and narrow sill.

The Aptian carbonaceous sediments at Site 361 (Unit 7 of that site, see Chapter 2) are overlain by over 650 meters of finely cross-laminated siltstones, mostly interbedded with red shales (Unit 6), deposited from the end of the Aptian to nearly the end of the Cretaceous. Unit 6 and Unit 7 together thicken considerably toward the South African coast. The top of Unit 7 forms a prominent reflector (Reflector AII of Emery et al., 1975, after the WHOI R/V Atlantis II) traceable along the Atlantic continental margin of most of southern Africa. Unit 6 represents an abrupt change from Unit 7 in terms of both sedimentary structures and in the almost complete decline in the abundance of organic carbon. Nothing like the coarse sandstones of Unit 7 are present in Unit 6, and the red shales plus absence of organic carbon are clear evidence that oxygenating conditions reached to the sea floor. During Leg 40 we inferred that in Albian times, the Agulhas fracture-zone sill had deepened and widened sufficiently to allow circulating oxygenated waters to reach the bottom of the Cape Basin (Bolli, Ryan, et al., 1975). At about this time, evaporite conditions ceased or nearly ceased in the Angola Basin, but restricted conditions persisted to the extent that carbonaceous shales and dolomitic limestones were deposited at Site 364 (see Figure 1 for location) during the Albian and again during Coniacian-Santonian times.

A picture had thus emerged of a decline in the extremely restricted circulation prevalent in the South Atlantic during the Cretaceous, Consistent with the initial supply of seawater only from the south, the degree of circulation in the Cape Basin kept one step ahead of that in the Angola Basin as the South Atlantic widened. When the Cape Basin was anoxic, the Angola Basin was evaporitic. When oxygenating conditions developed in the Cape Basin, the Angola Basin also opened up a bit and became anoxic. Finally it too achieved sufficient circulation to become oxygenated for good in the Late Cretaceous. 


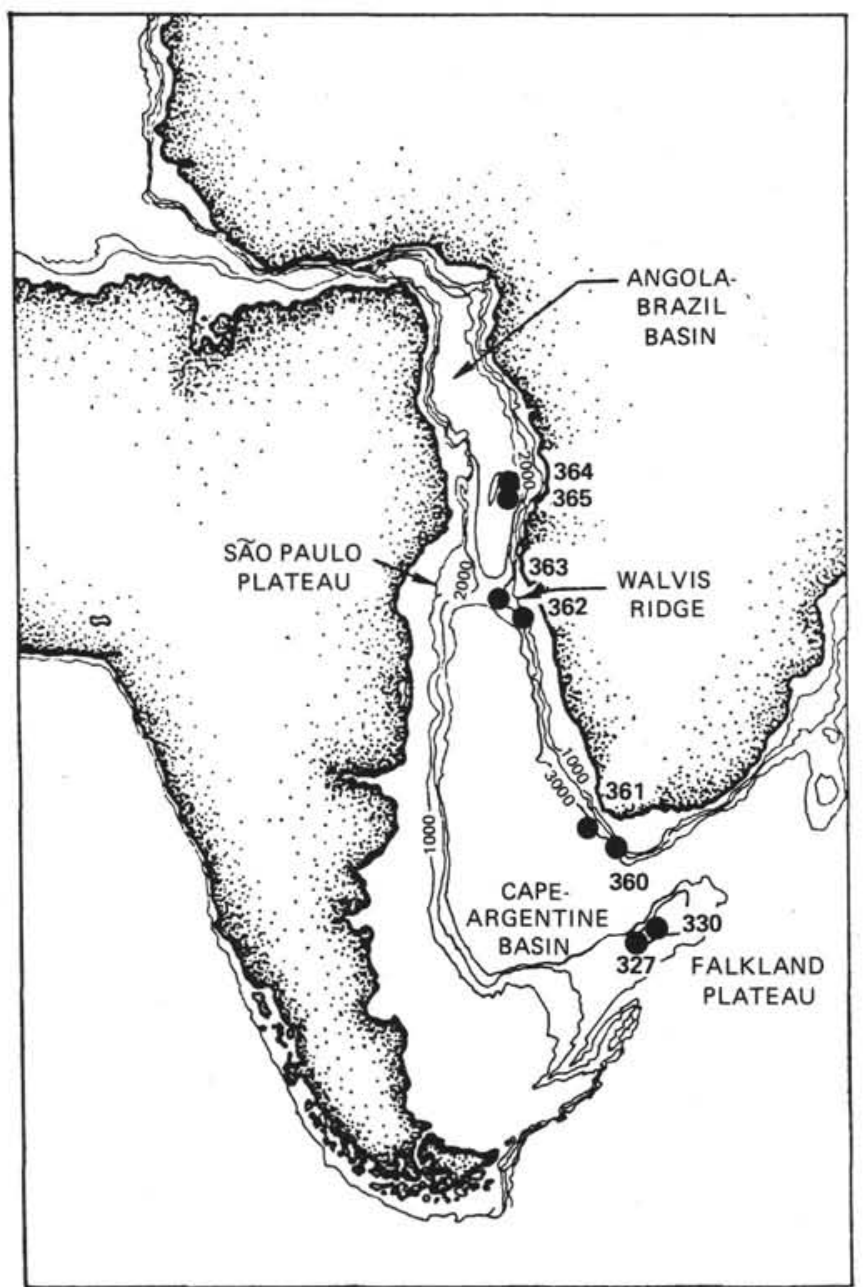

Figure 1. Location of sites drilled on Leg 40 (360-365) with Africa and South America in their approximate Late Cretaceous positions. The Cape-Argentine Basin is open to the Indian Ocean by a narrow passage between the Falkland Plateau (which was largely emergent at that time) and southern Africa. The Angola-Brazil Basin was virtually landlocked and separated from the Cape Argentine Basin by the Walvis Ridge-São Paulo Plateau obstruction. Sites 327 and 330 on the Falkland Plateau reached Aptian sapropels similar to those of the same age at Site 361, but which were deposited in the deepest waters of the Cape Basin. The Cape Basin was therefore filled with anoxic waters that reached very shallow levels on the Falkland Plateau.

This paper presents descriptive chemical and mineralogical data on Cretaceous clastic sediments from Units 6 and 7 of Site 361. This information is used to refine the picture of the developing circulation of the South Atlantic briefly outlined above. Data and conclusions of several other papers of this volume are incorporated into descriptions and discussion here. The chief items that will be documented in this paper are (1) chemical data supporting a change in provenance from a restricted, primarily granitic terrane in Unit 7 , to a more northerly provenance involving a probable basaltic component derived from the Karroo Basin via the Orange River in Unit 6; (2) an unusual authigenic mineral assemblage in Unit 7 sandstones, kaoliniteillite-phillipsite, which appears to have required unusually saline bottom waters to have formed; (3) evidence that sedimentary structures in Unit 6 of Site 361 , and in correlative sediments at Site 363, were produced by currents, and are not necessarily representative of turbidites.

This information will be pieced together to develop a model for the circulation of the South Atlantic during the Cretaceous, given the geometric constraints of the linked pair of basins described above, and the known changes in lithology through time at Sites 361, 363, and 364.

\section{DESCRIPTION OF UNIT 7 SEDIMENTS}

The Cretaceous sediments of Site 361 have been divided into two units in the lithologic summary of Chapter 2 (this volume). The older, Unit 7, is 313.5 meters of Aptian black carbonaceous shale, coarse sandy mudstone, and calcite-cemented sandstone characterized by abundant organic carbon, plant debris including wood chips up to $10 \mathrm{~cm}$ long, and pyrite. Twenty-one cores (28-49) were taken in this unit, recovering 96.15 meters of material, or $48.2 \%$ recovery. The top of Unit 7 corresponds to Reflector AII (Emery et al., 1975; see Chapter 2, this volume) which defines a prism of sediments thickening markedly toward the South African coast, and which is traceable along most of the Atlantic margin of the Cape Basin. Near the outlet of the Orange River north of Site 361, sediments beneath Reflector AII are up to $3 \mathrm{~km}$ thick (Dingle and Scrutton, 1974).

Unit 7 sandstones range from several centimeters to several meters thick and increase in thickness and abundance deeper in the hole. They generally have sharp basal contacts with adjacent shale beds and many have well-defined grading or cross-bedding (Plate 1, columns 1 and 2). Graded bedding appears as a transition from coarse fairly clean sands to darker clay and sands rich in organic fragments, and then to alternating thin laminae of sands or clayey silts and black shales. Erosional and slump features occur in some beds (Plate 1, Column 1).

There are two types of sandstone, one solidly cemented by calcite (Plate 1, Column 2), the other, which is more abundant, poorly cemented by clays (Plate 1, Columns 2 and 3). The calcite-cemented variety is fairly clean and well sorted and consists mostly of quartz grains, microcline, and plagioclase, with accessory biotite, muscovite, magnetite, tourmaline, and zircon. The calcite cement encloses these grains poikilitically (Plate 3, Figure 1). Faint crossbedding can be seen on sawed surfaces of these sandstones (Plate 1, Column 1).

The poorly cemented sandstones are those that most often show the graded bedding just described. The mineralogy of the poorly cemented sandstones is the same as the calcite-cemented sandstones, but their clay fraction is very large and includes abundant grains of shale (Plate 3, Figures 2-4), many of which preserve original bedding features such as clay orientation or a generally flat appearance in appropriate cross-sections. 
Much of the matrix evidently came from crushing such grains. The shale grains contain finely divided carbonaceous material. Pyrite can also be seen in reflected light (see Frontispiece) but no estimate of its mode can be given because of the difficulty of polishing the soft grains in thin sections of these quartzose sandstones. A distinctive feature of these clay-cemented sandstones is the extreme angularity of the quartz grains (Plate 3, Figure 5). No quartz overgrowths occur on quartz grains of any of the sandstones examined in thin sections. The high proportion of clays in smear slides of these sandstones results in their being termed sandy mudstones using the DSDP classification, but most of the clay is in these lithic sand grains, and in matrix material derived by crushing such lithic grains.

Carbonaceous material is most abundant in the shale beds, which are blackened by its appearance. The total inorganic carbon content in the shales ranges from $0.7 \%$ to $10.7 \%$, with an average of $3.75 \%$ (27 determinations from Foresman, this volume; Kendrick et al., this volume; and DSDP Sediment Laboratory, reported on Site chapter core forms). Much octahedral pyrite, and some framboidal pyrite occur in these shales (Noël and Melguen, this volume; see their Plates 1 and 2). In a few instances pyrite forms large lumps up to 2 $\mathrm{cm}$ in diameter (cf. Core 28, Section 5). The organic carbon occurs as wood chips, palynomorphs, microscopically amorphous carbon, or immature petroleum (MacLachlan and Pieterse, this volume; Foresman, this volume). The shales emitted a strong petroliferous odor when first brought on deck and could be ignited with a match.

Organic carbon in the clay-cemented sandstones is almost as abundant as in the shales, averaging $3.57 \%$, but it ranges from $0.7 \%$ to $14.6 \%$ (also 27 determinations), in general showing wider scatter. It is typically coarser, including a greater proportion of wood fibers and chips (some up to $10 \mathrm{~cm}$ long, but most $1-3 \mathrm{~mm}$ long). Associated pyrite is usually framboidal (Plate 4, Figures 1-3, and Frontispiece). The larger wood chips are oriented parallel to bedding as are many of the flatter quartz chips and the micas. Fine carbonaceous matter, though, is fairly abundant, usually matted around or between detrital grains (Plate 4, Figure 4). In these instances, pyrite is usually concentrated toward the center of the mats and is invariably framboidal. Much pyrite in the sandstones, however, has been reworked or incorporated from shales or other sandstones and is not associated with carbonaceous matter (Plate 4, Figure 1).

Organic carbon is minor in the calcite-cemented sandstones (only three determinations, $0.4 \%, 0.5 \%$, and $0.9 \%$ ). No large wood chips occur in these.

The more massive shales, some of which are several meters thick, are soft and fissile. Bedding is hard to see except in the rare instances where nannofossil interlayers are present. In Core 33, Section 3, for example, there are literally hundreds of fine, almost varve-like nannofossil layers alternating with equally fine layers of black shale above the graded bedding sequence shown on Plate 1, Column 1. Another such sequence occurs in Core 35 (Plate 1, Column 3; see also Frontispiece).
This type of bedding indicates very tranquil bottom conditions. Indeed, some of these nannofossil layers have only single species of nannofossils, such as Nannoconus, or a very few species only (Noël and Melguen, this volume). Most of the layers, though, are of high diversity. In all layers, fossils are broken into fragments, but usually all the fragments of any one nannofossil are clumped together. They therefore have not been mixed by bottom currents. The low species diversity of some of the layers is taken by Noël and Melguen to imply limpid surface waters of the Cape Basin. The fossils were not disaggregated by dissolution en route to the sea floor, nor mechanically mixed as they descended or after they reached the bottom.

Kagami (this volume) used grain size analysis and a statistical treatment of bedding thickness to propose that Unit 7 sandstones were deposited as dense traction or debris flows never fully suspended in seawater during transport, that some of them in fact were transported as bed loads in channels, and that the associated shales appear to be related to underlying sandstone beds, and were deposited in "the same sedimentary events." Presumably they represent the fine particles settled out of the upper portions of turbidity currents or water entrained in traction flows.

Thin-section observations add to this picture. It is plausible that the "sandy mudstones" are a mechanical mix of two end components-coarse, fairly clean quartzfeldspar sands, and soft carbonaceous muds. A traction flow of heavy sand across soft mud would be bound to rip up and incorporate the soft muds, giving both the matrix and the lithic shale grains observed in thin sections. Development of this traction flow into a fastmoving density flow could then promote mechanical sorting of light carbonaceous matter, clays, and sands in the density flow, finally resulting in deposition of shales above sands "in the same event" (cf. Plate 1, Column 1).

The tranquil conditions of deposition of some shales discussed by Noël and Melguen (this volume) are at odds with this picture. Surely delicate nannofossil structures would never survive such catastrophic incorporation of muds into sands. At least some of the shales therefore cannot be related to underlying sandstones "in the same event."

As discussed in the lithologic and biostratigraphic summaries of Chapter 2, lack of ostracodes, molluscs, and benthic organisms in Unit 7 sandstones suggests little or no residence time for these sediments in nearshore or marine shelf environments. Those sections speculated that the sediments were virtually the direct offshoots of river channel and delta systems, bypassing these shallow "staging areas." Since there is no evidence for incorporation of muds or other sediments deposited in an oxygenated environment into the coarse clayey sandstones of Unit 7, there is some reason to believe the top of the anoxic water mass was quite shallow even though Unit 7 was probably deposited in over 2000 meters of water. The abundant authigenic pyrite, lack of burrows and benthic organisms, the almost varve-like nannofossil layers, and the deposition of single species of nannofossils without disaggregation 
in the water column (Noël and Melguen, this volume) are all evidence for a deep, anoxic, and at times stagnant water mass.

Further evidence for a deep anoxic water mass in the Cape Basin was provided at Sites 327 and 330 drilled on the Falkland Plateau on Leg 36 (see Figure 1). Both sites penetrated Aptian carbonaceous shales inferred to have been deposited in an euxinic environment (Barker, Dalziel, et al., 1977). At Site 330, these sediments are thought to have been deposited at shelf depths (100-400 $\mathrm{m}$ inferred from foraminiferal evidence; Sliter, 1977), and because the sapropels were deposited above an apparent arkosic beach sand, fluviatile deposits, and a gneiss-granite pegmatite-syenite basement complex. The cessation of anoxic conditions at Sites 327 and 330 at the end of the Aptian coincides with that at Site 361. The Leg 36 Shipboard Party, however, speculated that the shallow carbonaceous sediments at Site 330 may have been deposited within a shallow oxygen-minimum layer which may have existed through much of the world ocean, allowing deposition of Aptian carbonaceous sediments at Site 317 on the Manihiki Plateau in the central Pacific (Schlanger, Jackson, et al., 1976) and at Sites 305 on Shatsky Rise and 310 on Hess Rise (Larson, Moberly, et al., 1975). But this oxygenminimum layer would only explain carbonaceous sediments on high-standing features such as seamounts, rises, and plateaus. Carbonaceous sediments deposited in deep pelagic environments such as at Site 361 are best explained by relatively dense anoxic water masses blocked by sills. Additional evidence for such a dense water mass at Site 361 is discussed below under the section on Unit 7 diagenesis. But if an oxygenminimum layer was responsible for the Site 330 sapropels, it is likely. that there was no "oxygenmaximum" between this layer and the anoxic bottom waters of the Cape Basin. Instead, except for surface waters, the entire Cape Basin was probably stagnant, oxygen-starved, and occasionally limpid during the Aptian. Muds carried to sea by spring floods settled to the sea floor. When the waters were clearer, nannofossil blooms added thin layers of white dust to the sediment. The bottom stillness was broken only by periodic floods of coarse sand. The coarse, clay-rich sandstones which grade into laminated sandy and shaley layers exhibit most of the classic Bouma (1962) sequence of turbidites (Plate 1, Column 1). The shaley sand grains and much of the clay matrix probably represent materials ripped from shale beds and entrained in the density flows. The better sorted, calcite-cemented sandstones apparently were not, however, turbidites or traction flows. Their sorting may have occurred in the higher energy beach or nearshore environment, and they may represent channel deposits, as suggested by their fine internal bedding (Plate 1, Column 2).

In order of their ease of erosion, the dominant sources of sand to rivers in probable southern African source regions of Unit 7 sediments would have been (1) sandstones and shales of the Paleozoic Cape System, especially the Table Mountain series which has prominent exposures west of the Great Escarpment, the probable major divide in western South Africa during the Cretaceous (see Siesser, this volume); (2) Malmesbury Precambrian sediments and metasediments, again mostly sandstones and shales derived from older granitic terrane; (3) the Cape Granites, intruding the Malmesbury sediments between 500 and 600 million years ago (Nicolaysen, 1962; Allsopp and Kolbe, 1965). Both Malmesbury sediments and Cape Granites eroded to produce the Table Mountain Series.

These source regions almost certainly were rugged and had high relief. There was probably more relief than is typically associated with newly rifted continents because of (1) the naturally buoyant Cape Granites, and (2) the still fairly recent involvement of the region in the orogenic event which produced the Triassic Cape Fold Belt. Larson and Ladd (1973) estimate the South Atlantic to have opened about 127 million years ago (anomaly M-12). Rifting certainly began earlier than this and was accompanied by volcanism, probably both basaltic, represented by the Kaoko tholeiitic basalts in southwest Africa which are of about this age (Siedner and Miller, 1968), and silicic, represented by the Cape Cross, Okonjeje, Erongo, and related complexes in southwest Africa (Martin et al., 1960). These silicic centers probably arose mainly by melting of continental crust and appear to be analogous to basalt-rhyolite volcanoes of Somalia and the southern Arabian Peninsula adjacent to the Gulf of Aden today (Beydoun, 1970; Gass, 1970). But if such silicic centers reached to the tip of southern Africa, as suggested in Chapter 2 of this volume, their roots are now buried beneath the continental margin sediments west of Cape Province. Only scattered basalt dikes are now exposed south of the Orange River (Haughton, 1969). Nevertheless, sand grains with a silicic volcanic source occur in Unit 7 sandstones, especially from Cores 40-48 (see Chapter 2), and it is probable that they could only have been derived from a source of this type.

\section{DESCRIPTION OF UNIT 6 SEDIMENTS}

The younger Cretaceous unit of Site 361 , Unit 6, is 636.5 meters of upper Aptian/Albian to Maestrichtian reddish brown or gray fissile shale interbedded on a scale of 1 to $10 \mathrm{~cm}$ with finely laminated and crosslaminated gray siltstone. Fifteen cores were taken, recovering 75.0 meters of sediment, representing a recovery rate of $52.7 \%$. The red shales are interbedded with the siltstones in all but Cores 22-24 and 27. These cores have gray rather than red shales interbedded with the siltstones.

Representative sedimentary structures of Unit 6 are illustrated in Plate 2, Columns 1 and 2. Column 1 shows siltstones and carbonate beds interlayered with dark shales. In contrast to Unit 7, in which the carbonates show extremely fine parallel laminations, here they have been smeared and to some extent mixed with surrounding clays by bottom currents. Carbonates are only present in Cores 26 and 27 of Unit 6 (Noël and Melguen, this volume; Siesser and Bremner, this volume). Above this, sediments were deposited below the carbonate compensation depth (Melguen, this volume). Core 27 is the youngest core to have sediments 
darkened by a significant component of carbonaceous matter with the restricted pollen assemblage of Unit 7 (MacLachlan and Pieterse, this volume). However, total organic carbon is much lower than in typical Unit 7 shales (less than $0.5 \%$ ). It is possible that much of the organic carbon in Core 27 is reworked, and therefore does not necessarily indicate that anoxic bottom conditions still persisted. The darker appearance of Cores 22-24 is also partly due to a small organic carbon component. The pollen, however, are strikingly more diverse than in Core 28 of Unit 7, indicating a source with a warmer, less harsh climate (MacLachlan and Pieterse, this volume). This supports evidence (to be presented) from the chemistry of the sediments that Unit 6 has a more northerly provenance than Unit 7. The presence of well-preserved palynomorphs and a small amount of organic carbon in Cores 22-24 could imply a return to somewhat anoxic conditions during the times when these sediments were deposited. The palynomorphs allow only Cores 22-24 and 27 out of all of Unit 6 to be dated. The times coincide with periods when anoxic conditions existed in the Angola Basin at Site 364 (Albian and Coniacian/Santonian).

Plate 2, Column 2, illustrates typical sedimentary structures of cores containing alternating red shales and siltstones. The upper few centimeters of Column 2 show a very fine interlayering of red clay and silt layers. Our initial shipboard interpretation of the siltstones and sedimentary structures of the rhythmically bedded Unit 6 was that they represented the distal portion of turbidites. Kagami (this volume) also favors this interpretation. We supposed that the effects of subsidence and erosion of sourcelands would be a diminishing of the massive turbidites and traction flows of Unit 7 to thinner and finer grained sediments of the type recovered in Unit 6 . However, if Unit 6 were considered by itself without the knowledge of the Unit 7 turbidites, there would be little justification for calling the silty layers "distal portions" of turbidites rather than "contourites"- sediments redistributed and sculpted by bottom currents. The finely interlayered clay and silt layers at the top of Column 2 are, I believe, the type of sedimentary structure favoring the contourite interpretation.

Hollister and Heezen (1973) discuss the critical differences between turbidites and contourites. Although a part of the Bouma sequence has bedforms similar to Unit 6 siltstones, this is largely an accident of fluid dynamics. By and large, turbidites are massive, muddy, poorly sorted sands, grading into better-sorted, cross-bedded silts, and hence to shales. In essence, Unit 6 totally lacks massive, muddy sands or sandstones of any kind. The crucial evidence for turbidites does not exist. Cross-bedding by itself is not sufficient evidence that the flow regime was associated with a density flow of material suspended in water rather than bottom currents. Hollister and Heezen (1973) cite one distinctive feature of contourites of use here. The contrasts in individual layers or laminae in crossbedded portions of turbidites result from different proportions of clays-clay-rich and quartz-poor layers alternate with clay-poor, quartz-rich layers. But in contourites, quartz-rich layers alternate with "placers," layers rich in heavy minerals. Figure 2 shows a blow-up of a thin section of a calcite-cemented siltstone from Unit 6. In this photograph, the quartz-rich layers appear darker because of the greater proportion of calcite cement surrounding the looser packed, larger quartz grains. Tiny wood chips, black in Figure 2, are concentrated in the quartz layers. The light-colored layers contain no low-density wood chips, less quartz (and what there is is finer grained), and more heavy minerals and rock fragments. The latter include amphibole and, most abundant, altered lithic grains, now mostly chlorite.

Hollister and Heezen (1973) note that contourites can be gradational with turbidites. Their type contourite, though, a sequence of alternating siltstones and red clays beneath the Western Boundary Undercurrent on the Atlantic continental rise of the United States, is uncannily similar to Unit 6 . Their red clays originate in the Cabot Strait off Newfoundland and are transported by the Western Boundary Undercurrent thousands of kilometers to the Blake-Bahama Outer Ridge.

Similar sedimentary structures and a sedimentary section shortened by erosion suggest that Late Cretaceous sediments of Site 363 (Walvis Ridge) have also been affected by bottom currents (Plate 2, Column 3 ; and Chapter 3, this volume). The time of strongest evidence for erosion atop Walvis Ridge, then, coincides with the development of contourites at Site 361, and is

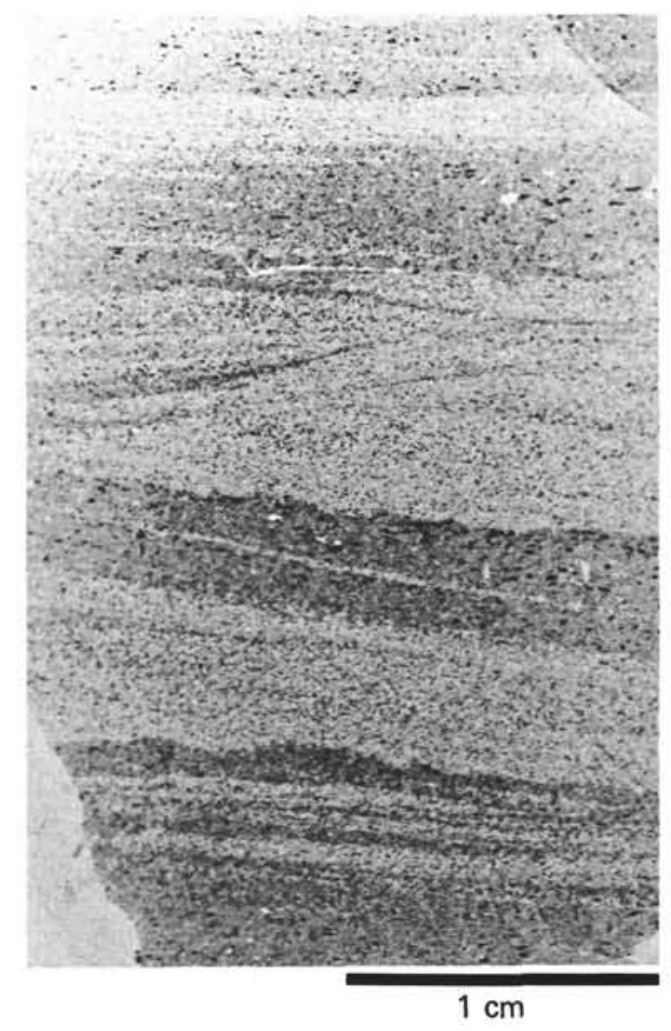

Figure 2. Fine-scale cross laminations, evidence for bottom currents, revealed in a thin section of carbonate-cemented siltstones from Unit 6 of DSDP Site 361, Core 22, core catcher. 
also the only time when carbonaceous and pyritic sediments accumulated at Site 363 .

Deep thermohaline circulation, then, might be responsible for the sedimentary structures of Unit 6, and simultaneously for the erosion and redeposition of sediments at Site 363 . The marked change in the diversity of palynomorphs between Cores 22-24 and 27 of Site 361 supports this. We now seek further evidence for this in the chemistry of Unit 6 and Unit 7 sediments.

\section{CHEMISTRY AND PROVENANCE}

\section{Analytical Methods}

Chemical analyses of sediments from Site 361 were obtained by X-ray fluorescence $\left(\mathrm{SiO}_{2}, \mathrm{Al}_{2} \mathrm{O}_{3}, \mathrm{FeO}^{*}\right.$, $\mathrm{CaO}, \mathrm{K}_{2} \mathrm{O}, \mathrm{TiO}_{2}, \mathrm{Ba}$, and $\mathrm{Zr}$ ) and atomic absorption ( $\mathrm{MgO}, \mathrm{Na}_{2} \mathrm{O}, \mathrm{MnO}, \mathrm{Sr}, \mathrm{Rb}, \mathrm{Ni}, \mathrm{Cr}, \mathrm{U}, \mathrm{Cu}, \mathrm{Zn}$, and $\mathrm{Pb}$ ) techniques. Samples were first powdered then dried at $110^{\circ} \mathrm{C}$ to remove moisture $\left(\mathrm{H}_{2} \mathrm{O}^{-}\right)$. Major element XRF data were obtained using polished fused glass discs with a $\mathrm{LiBO}_{2}$ flux and $\mathrm{La}_{2} \mathrm{O}_{3}$ suppressant, and calibrated to least-square lines of intensity versus concentration for up to 20 U.S., French, Canadian, South African, and Japanese international reference standards. Minor element XRF data were obtained on powder pellets consisting of three grams of sample and one gram of Whatman chromatographic cellulose pressed to 25 tons between polished dies. These were calibrated to least-square lines to reference standards after instrumental and matrix corrections were applied based on the method of Bougault et al. (in press). For atomic absorption analyses, $1 \%$ stock solutions were prepared by dissolving 0.5 gram of sample in HF in sealed teflon bombs heated to $100^{\circ} \mathrm{C}$. These were dried over a low temperature hot plate, then redissolved in 6-ml concentrated nitric acid and diluted with double distilled water to $50 \mathrm{ml}$. Method of additions was used for $\mathrm{Cr}, \mathrm{Sr}$, and $\mathrm{Zn}$. $\mathrm{MgO}, \mathrm{Na}_{2} \mathrm{O}, \mathrm{MnO}$, and $\mathrm{Rb}$ were measured by direct comparison with USGS standards dissolved and diluted in the same manner. $\mathrm{Ni}, \mathrm{V}$, and $\mathrm{Pb}$ were determined from the $1 \%$ solutions using a heated graphite atomizer attached to the Perkin-Elmer Model 403 Atomic Absorption Spectrophotometer. A deuterium arc background corrector was used for the HGA measurements which were again calibrated to USGS standards. The estimated precision and accuracy of the analyses are listed in Table 1. Organic carbon and $\mathrm{CaCO}_{3}$ were determined at the DSDP Sediment Laboratory using a LECO 70-Second Analyzer. The method used is described in Boyce and Bode (1970).

Four clay-rich sandstones and one carbonaceous shale were analyzed from near the bottom of Unit 7 of Sit 361 . Three shales, two red and one gray, and one siltstone were analyzed from Unit 6.These analyses are listed in Table 1, both as determined (A columns), and normalized to $100 \%$ $\mathrm{CaCO}_{3}$ - and carbon-free (B columns). The difference between the totals of the analyses as determined and $100 \%$ is mainly the percentage of combined water, plus small amounts of sulfur, and oxygen combined with $\mathrm{Fe}_{2} \mathrm{O}_{3}$ rather than $\mathrm{FeO}$. The combined water in clays can be very high depending on the clay mineral. From tables in Grim (1964) and Deer et al. (1962) "illite" averages $6.7 \% \mathrm{H}_{2} \mathrm{O}^{4}$, kaolinite $13.79 \% \mathrm{H}_{2} \mathrm{O}^{4}$, and the various montmorillonite minerals $6.74 \% \mathrm{H}_{2} \mathrm{O}^{4}$. However, montmorillonite can have between $13 \%$ and $17 \%$ "uncombined" water that can be driven off anywhere between $110^{\circ}$ and $300^{\circ} \mathrm{C}$ (Deer et al., 1962). Dehydration curves in Grim (1964) indicate that between $100^{\circ}$ and $300^{\circ} \mathrm{C}$, montmorillonite can lose up to $6 \%$ by weight in water, illite up to $1.5 \%$, and kaolinite up to $1 \%$. Site 361 samples were dried at $110^{\circ}$, which probably drove off most uncombined water in kaolinite and illite, but probably not in montmorillonites or mixed-layer smectite-illites which occured in Unit 6 shales. This is probably the explanation for the lower totals in Unit 6 sediments. Among the Unit 7 sediments, the somewhat low totals almost certainly reflect the dominace of illite among the clays, as indicated by $\mathrm{X}$-ray diffraction data (Siesser and Bremner, this volume). I have listed all iron as $\mathrm{FeO}\left(\mathrm{FeO}^{*}\right)$, even though probably most of it is as $\mathrm{Fe}_{2} \mathrm{O}_{4}$.

In the following, names given to clay minerals are general, especially when discussing whole-rock chemistry. Thus "kaolinite"' refers to kaolinite-group minerals, including dickite and halloysite. Montmorillonite and smectite are used fairly interchangeably, depending on whom I am referencing or discussing. Smectite-illite, for example, is the term used by Stonecipher $(1967 \mathrm{a}, \mathrm{b})$ for mixed layer clays produced by diagenesis of smectites (or montmorillonites).

\section{Unit 7}

$\mathrm{CaCO}_{3}$-free data are plotted on Figures 3-6. Figures 3 and 4 deal with sandstone and siltstone data only, establishing that all four Unit 7 sandstones and the Unit 6 siltstone are chemically similar to arkoses and to sandstones associated with rifting (taprogeosynclinal sandstones). The latter are mainly arkoses anyway. The Unit 7 sandstones contain so much clay, however, that they are probably better termed arkosic wackes (Pettijohn et al., 1972).

Figures 5 and 6 show the relationship of the proportions of $\mathrm{Al}_{2} \mathrm{O}_{3}$ to $\mathrm{CaO}$ and $\mathrm{K}_{2} \mathrm{O}$, and to $\mathrm{FeO}^{*}$ and $\mathrm{MgO}$, respectively. Both sediments and potential source rocks are indicated by either points or by limiting fields. Data for Cape Granites and component minerals are from Kolbe (1966) and are listed in Tables 2 and 3 along with other potential source-rock compositions. Fields for kaolinite, illite, and marine and non-marine montmorillonites (saponites, nontronites, etc.) are based on tables in Deer et al. (1962), Grim (1964), and Dalrymple and Clague (1976). The marine montmorillonite data are all from alteration products in basalts whereas the non-marine field includes clays from more aluminous sources, such as andesite. The principal differences among the clays are that marine (basaltic) montmorillonite is lower in $\mathrm{Al}_{2} \mathrm{O}_{3}$, and all montmorillonites are higher in $\mathrm{FeO}^{*}$ and $\mathrm{MgO}$ than kaolinite and illite. Marine montmorillonite is also more potassic on the whole, than even illite. Comparison of marine and non-marine 
TABLE 1

Composition of Site 361 Sediments

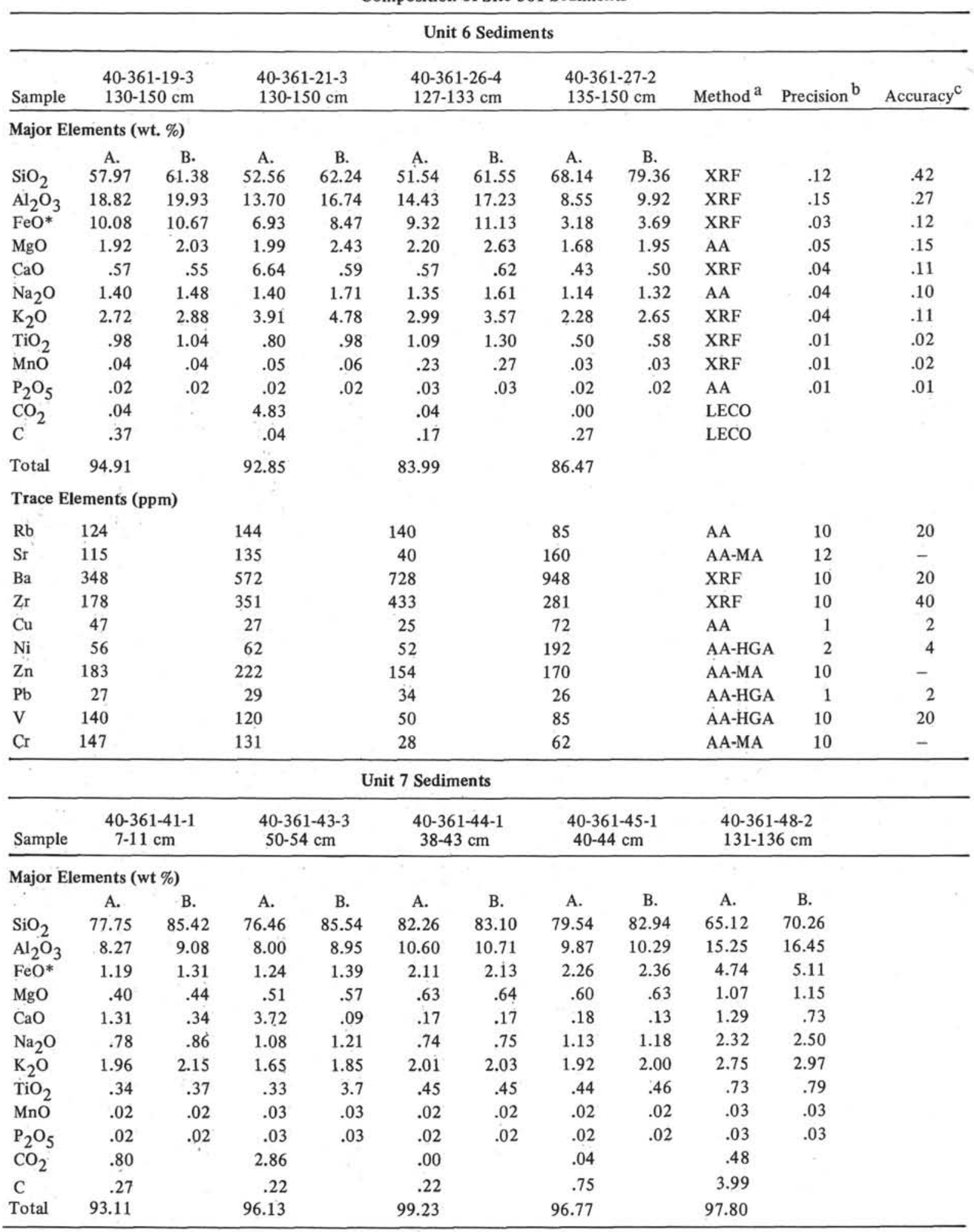

montmorillonites shows how much $\mathrm{K}$ can be taken up by this mineral in seawater. Presumably detrital low-K montmorillonite can pick up considerable potassium once it leaves rivers and enters the sea. Grim (1964) cites a cation exchange capacity for smectites (montmorillonites) of 2 to 15 times that of illite, and 4 to 50 times that of kaolinite, the ranges depending on particle size and other factors. The non-marine montmorillonites, then, are not reasonable potential contributing minerals to Unit 6 shales in terms of $\mathrm{K}_{2} \mathrm{O}$, but might be if the high $\mathrm{K}_{2} \mathrm{O}$ results from adsorption of $\mathrm{K}$ in seawater. Unit 6 sediments, then, appear to have a mafic or montmorillonitic component based on their higher $\mathrm{FeO}^{*}$ and somewhat higher $\mathrm{MgO}$ than Unit 7 
TABLE 1 - Continued

\begin{tabular}{|c|c|c|c|c|c|}
\hline Sample & $\begin{array}{c}40-361-41-1 \\
7-11 \mathrm{~cm}\end{array}$ & $\begin{array}{l}40-361-43-3 \\
50-54 \mathrm{~cm}\end{array}$ & $\begin{array}{l}40-361-44-1 \\
38-43 \mathrm{~cm}\end{array}$ & $\begin{array}{c}40-361-45-1 \\
40-44 \mathrm{~cm}\end{array}$ & $\begin{array}{l}40-361-48-2 \\
131-136 \mathrm{~cm}\end{array}$ \\
\hline $\mathrm{Rb}$ & 79 & 63 & 79 & 74 & 122 \\
\hline $\mathrm{Sr}$ & 50 & 103 & 75 & 50 & 100 \\
\hline $\mathrm{Ba}$ & 406 & 322 & 438 & 380 & 507 \\
\hline $\mathrm{Zr}$ & 335 & 383 & 450 & 387 & 394 \\
\hline $\mathrm{Cu}$ & 7 & 8 & 8 & 9 & 25 \\
\hline $\mathrm{Ni}$ & 20 & 18 & 20 & 22 & 48 \\
\hline $\mathrm{Zn}$ & 47 & 181 & 158 & 69 & 302 \\
\hline $\mathrm{Pb}$ & 9 & 18 & 20 & 18 & 41 \\
\hline $\mathrm{V}$ & 27 & 37 & 30 & 34 & 185 \\
\hline $\mathrm{Cr}$ & 44 & 27 & 66 & 65 & 68 \\
\hline
\end{tabular}

Note: All iron as $\mathrm{FeO}^{*}$. A. Analysis as determined. B. Analysis computed carbon- and $\mathrm{CaCO}_{3}$-free and normalized to $100 \%$. ${ }^{\text {Methods: }} \mathrm{AA}=$ Atomic absorption, $\mathrm{XRF}=\mathrm{X}$-ray fluorescence, $\mathrm{AA}-\mathrm{MA}=$ Method of additions with atomic absorption, $\mathrm{AA}-\mathrm{HGA}=$ Atomic absorption using a heated graphite atomizer, $\mathrm{LECO}=$ LECO 70-Second Analyzer. ${ }^{b}$ Precision is instrumental repeatability, for XRF computed as a standard deviation for at least 20 repeated measurements; for AA as standard error to least-squares fit for method of additions. ${ }^{c}$ Accuracy is standard error to least-squares linear regression for up to 20 international reference standards used for calibration for each element. Only USGS standards were used for AA trace element calibrations.

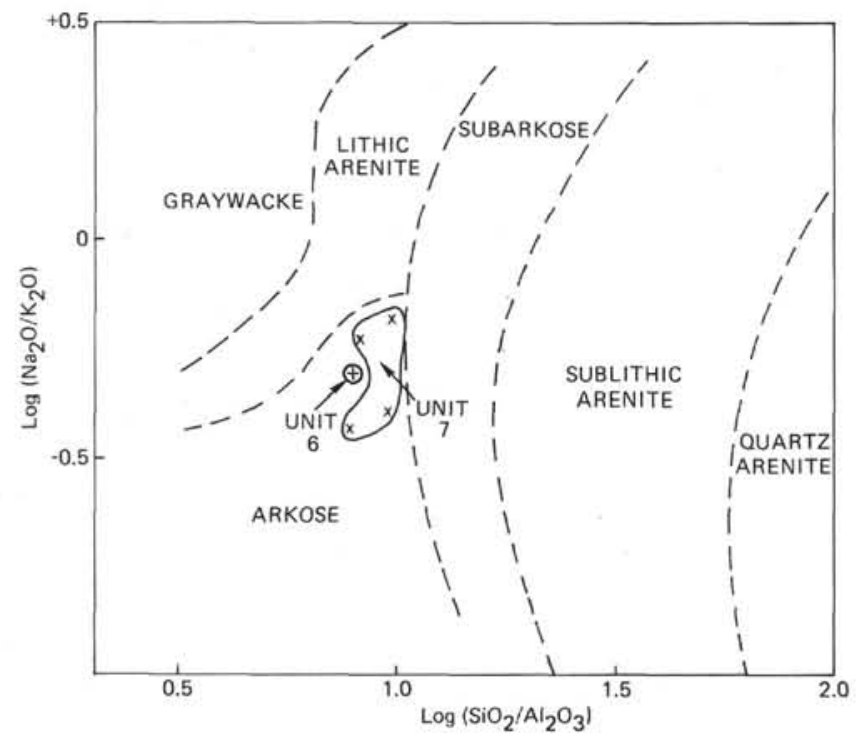

Figure 3. $\mathrm{Log}\left(\mathrm{SiO}_{2} / \mathrm{Al}_{2} \mathrm{O}_{3}\right)$ versus $\log \left(\mathrm{Na}_{2} \mathrm{O} / \mathrm{K}_{2} \mathrm{O}\right)$ for unit 7 sandstones and Unit 6 siltstone, from diagram in Pettijohn et al. (1972).

sediments, and their intermediate position between the illite and montmorillonite fields on Figure 6.

On Figure 5, the Cape Granites are seen to lie about midway between their component microclines and plagioclases (see Table 2). Feldspathic sandstones derived from Cape Granites (point FS, see Table 2) also fall on the line between the plagioclases and microclines. The granites are also centrally located in the arkose field, which is based on analyses of representative worldwide arkoses listed in Pettijohn, Potter, and Siever (1972). In contrast to the indications of Figures 3 and 4, Figure 5 shows that Unit 7 sandstones are much more aluminous than typical arkoses, potential Cape fold-belt source rocks, or feldspars, falling very close to the illite field on its

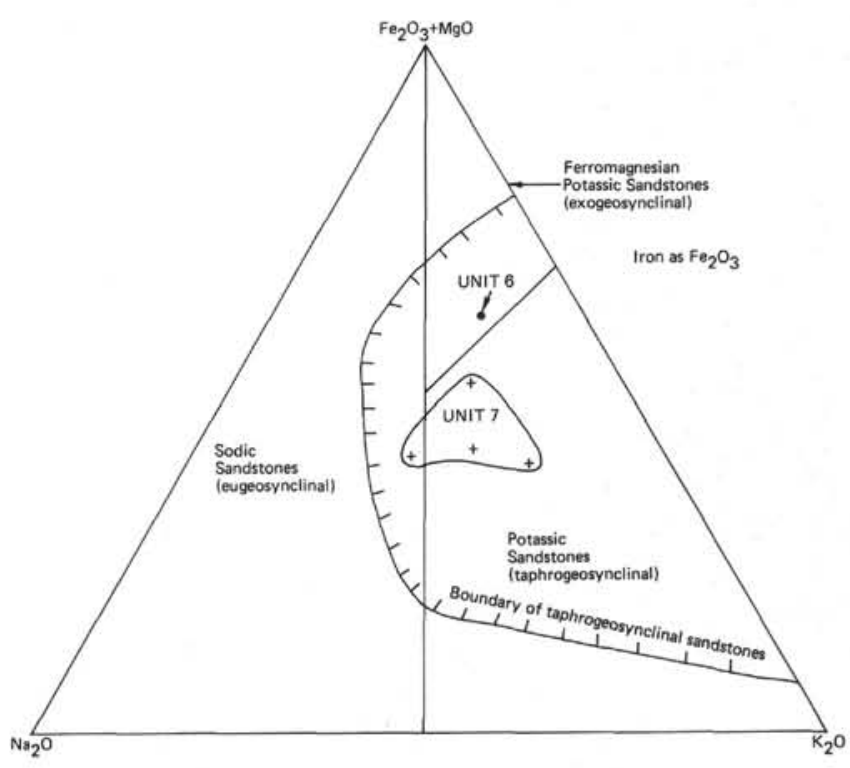

Figure 4. Triangular $\mathrm{Na}_{2} \mathrm{O}-\mathrm{K}_{2} \mathrm{O}-\mathrm{Al}_{2} \mathrm{O}_{3}$ diagram showing relation of composition of Unit 7 sandstones and Unit 6 siltstone to sandstones of various geosynclinal environments. The sediments fall within the field of taphrogeosynclinal (rift-valley) potassic sandstones.

aluminous (kaolinitic) side. They fall within the illite field as well on Figure 6 (except for Sample 361-48-1, which has some excess iron due to pyrite, for which the analysis has not been corrected).

Essentially, then, the non-quartz component of each Unit 7 sandstone has the composition of illite, with lesser kaolinite, and minor feldspar. A rough estimate can be made from Figure 5 using the ternary lever rule. Using "pure end-member" kaolinite $\left(\mathrm{CaO}\right.$ and $\mathrm{K}_{2} \mathrm{O}$ free), a point in about the middle of the illite field, and the point for average coarsely porphyritic Cape Granite (from Table 2), the non-quartz component of Sample 


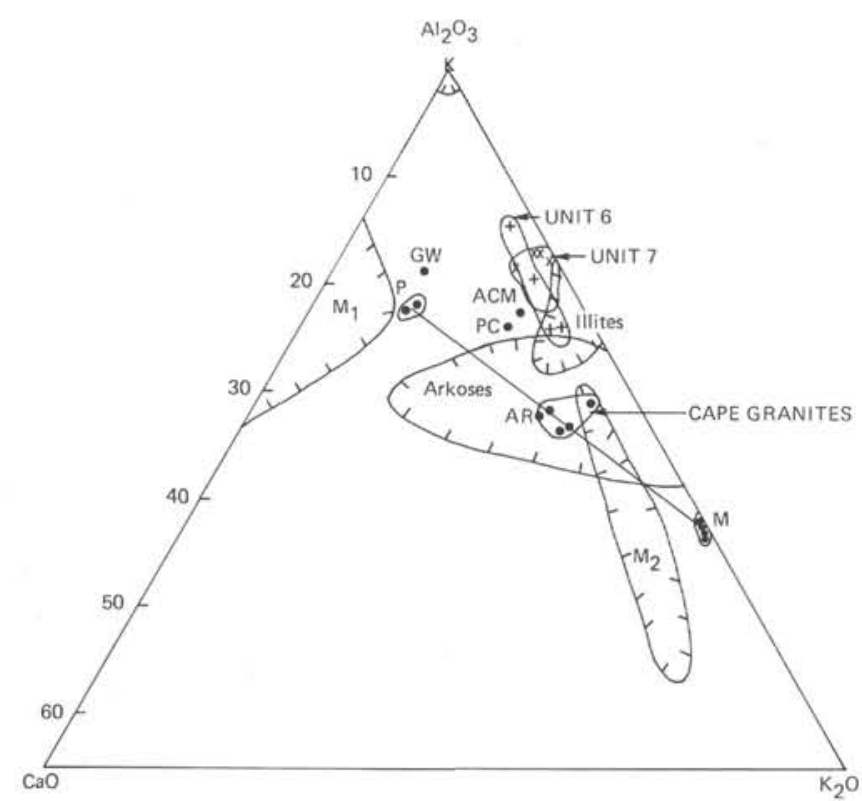

Figure 5. $\mathrm{CaO}-\mathrm{K}_{2} \mathrm{O}-\mathrm{Al}_{2} \mathrm{O}_{3}$ triangular diagram relating compositions of Units 6 and 7 analyzed sediments to potential source rocks and minerals. Cape granites, plagioclase, microcline, and average Cape metasediment (ACM) compositions are from Tables 2 and 3. Non-marine montmorillonite (MI), illite (I), and kaolinite (K) fields are from data in Grim (1964) and Deer et al. (1962). Marine montmorillonite and altered glass field $\left(M_{2}\right)$ from Dalrymple and Clague (1976). Average graywacke (GW) composition is from Pettijohn (1975). Field of arkoses from analysis in Pettijohn (1975). AR is average of nine low-CaCO $\mathrm{CO}_{3}$ arkoses from Pettijohn (1975). Pelagic clay (PC) composition is from Hughes (1969) average of pelagic clay analyses from Core CUSP-15 $\left(37^{\circ} 07^{\prime} N\right.$, $143^{\circ} 07^{\prime} \mathrm{W}$ ) in the central North Pacific.

$361-41-1$ is $82 \%$ illite, $8 \%$ kaolinite, and $10 \%$ "granite" feldspars (about $5 \%$ each microcline and oligoclase). The total clay to feldspar ratio of sandstones observed in thin section is probably even higher than this, and only about $2 \%$ of the coarse fraction of several sandstones investigated for SEM studies (see below) is feldspar. The high $\mathrm{SiO}_{2}$ of the sandstones indicates that they are between $55 \%$ and $60 \%$ quartz (based on normalized analyses in Table 1 and mineral data in Table 3).

Most of the clay in Unit 7 sandstones, then, cannot be of diagenetic origin. These are not merely badly altered arkoses. The clays, mostly illite, are detrital. Xray diffraction data of Unit 7 sediments verify that illite far predominates over kaolinite in the clay fractions and that montmorillonite and mixed-layer clays are absent (Siesser and Bremner, this volume).

Figures 7-11 use trace element data to assess the origin of so much detrital clay. "Illite" can form by degradation of muscovite or $\mathrm{K}$-feldspar. The ratios $\mathrm{K} / \mathrm{Ba}, \mathrm{K} / \mathrm{Sr}, \mathrm{Rb} / \mathrm{Ba}, \mathrm{Rb} / \mathrm{Sr}$, and $\mathrm{K} / \mathrm{Rb}$ appear to match most closely the ratios of coarsely porphyritic Cape Granite, the first and most voluminous phase of Cape plutonism (Scholtz, 1946; Kolbe, 1966; see Table 2). Apart from Sr, which appears to be slightly high in

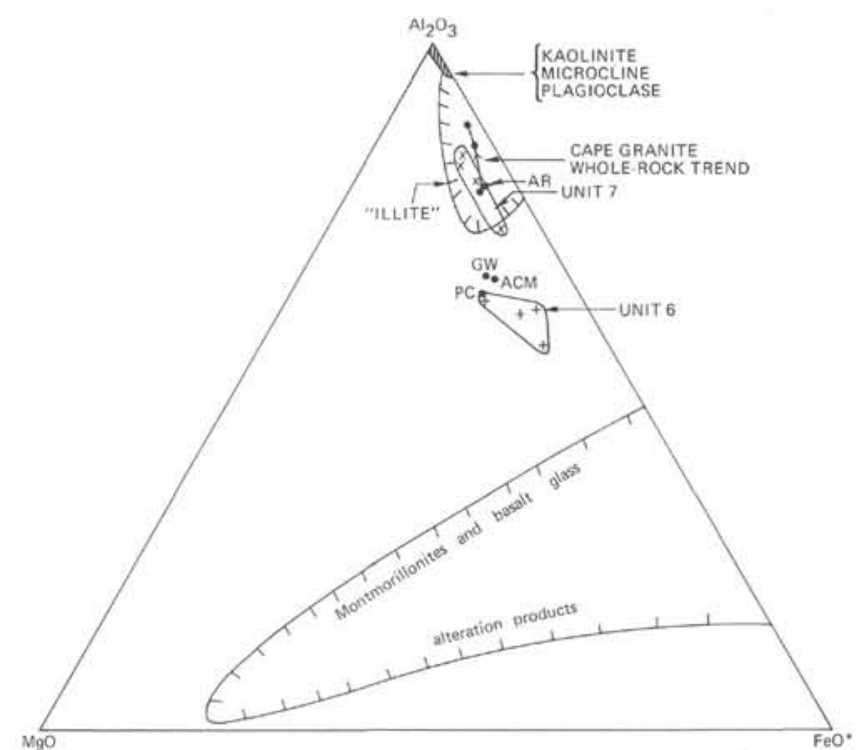

Figure 6. $\mathrm{MgO}-\mathrm{FeO} *-\mathrm{Al}_{2} \mathrm{O}_{3}$ triangular diagram relating composition of Units 6 and 7 analyzed sediments to potential source rocks and minerals. Data sources for clay mineral fields, granites, and average rock composition same as those of Figure 5. Figures 6 and 7 account for most of the non-quartz bulk compositions of the analyzed Site 361 sediments.

two samples because of calcite cement, there is very good coherence among all these elements in the Unit 7 sediments. Among granitic source rocks for sandstones, these elements should typically show large, systematic changes, such as the trends from $A$ to $E$ in Figures 7-11, representing changes from diorites, to main-stage granites, thence to late highly fractionated granites, aplites, and pegmatites. This is because the divalent cations $\mathrm{Ca}, \mathrm{Sr}$, and $\mathrm{Ba}$ are systematically excluded from the alkali feldspar structure in that order with respect to $\mathrm{K}$ and $\mathrm{Rb}$ as fractionation proceeds. Hence Kolbe's (1966) data show sympathetic increases in K and Rb in feldspars with respect to $\mathrm{Ba}$ and $\mathrm{Sr}$ as the granites become more fractionated. Plagioclase, biotite, and muscovite appear to contribute little to whole-rock Cape Granite abundances of these elements, since they fall far off the whole-rock curves, either being too low in $\mathrm{Ba}$ and $\mathrm{Sr}$ (biotite and muscovite) or $\mathrm{K}$ and $\mathrm{Rb}$ (plagioclase). The whole-rock trends are clearly dominated by potassium feldspar.

The sandstones of Unit 7 have the $\mathrm{K}, \mathrm{Rb}, \mathrm{Ba}$, and $\mathrm{Sr}$ abundances of an average rock slightly less fractionated than coarsely porphyritic Cape Granite (point $\mathrm{C}$ on Figures 7-11), only they have experienced between $30 \%$ and $60 \%$ "dilution" by quartz relative to granites. The $60 \%$ figure applies to the sandstones, and is in agreement with our earlier estimate of quartz dilution based on $\mathrm{SiO}_{2}$. The non-quartz component of Unit 7 sandstones therefore carries the alkali and alkali earth fingerprint of main-stage Cape Granite microclines, with only minor contributions from plagioclase, biotite, muscovite, or more mafic rock compositions. But the major element composition of the non-quartz component is almost entirely that of illite. 
TABLE 2

Major $^{\mathrm{a}}$ and Trace Element Compositions, and Norms or Modes of Potential Site 361 Source Rocks

\begin{tabular}{|c|c|c|c|c|c|c|c|c|c|c|}
\hline & A & B & C & D & E & $\mathrm{F}$ & G & $\mathrm{H}$ & I & J \\
\hline $\mathrm{SiO}_{2}$ & 57.65 & 50.8 & $70.27 \pm 1.45$ & $74.26 \pm 1.03$ & $76.07 \pm 1.04$ & $76.08 \pm 1.66$ & $72.24 \pm 3.35$ & $71.30 \pm 3.46$ & $64.05 \pm 5.19$ & 64.23 \\
\hline $\mathrm{Al}_{2} \mathrm{O}_{3}$ & 15.2 & 17.01 & $14.58 \pm 0.87$ & $13.16 \pm 0.54$ & $12.93 \neq 0.91$ & $12.96 \pm 1.20$ & $13.93 \pm 1.37$ & $14.17 \pm 1.50$ & $16.39 \pm 2.68$ & 13.25 \\
\hline $\mathrm{FeO}^{*}$ & 9.71 & 9.91 & $3.32 \pm 0.57$ & $1.85 \pm 0.34$ & $1.07 \pm 0.42$ & $1.48 \pm 0.79$ & $2.41 \pm 1.10$ & $2.55 \pm 1.08$ & $6.23 \pm 1.68$ & 6.98 \\
\hline $\mathrm{MgO}$ & 2.72 & 5.55 & $0.92 \pm 0.26$ & $0.31 \pm 0.15$ & $0.07=0.04$ & $0.26 \pm 0.23$ & $0.63=0.46$ & $0.75=0.48$ & $2.48 \pm 1.00$ & 1.92 \\
\hline $\mathrm{CaO}$ & 7.49 & 9.02 & $1.64 \pm 0.41$ & $1.24 \pm 0.35$ & $0.59 \pm 0.26$ & $0.80 \pm 0.48$ & $1.52 \pm 0.84$ & $1.82 \pm 0.94$ & $1.18 \pm 0.67$ & 4.41 \\
\hline $\mathrm{Na}_{2} \mathrm{O}$ & 2.32 & 1.60 & $2.93=0.30$ & $3.04 \pm 0.21$ & $3.54=0.49$ & $2.89 \pm 0.59$ & $3.16 \div 0.56$ & $3.25 \pm 0.64$ & $2.44 \pm 0.51$ & 2.50 \\
\hline $\mathrm{K}_{2} \mathrm{O}$ & 1.95 & 1.10 & $5.00 \pm 0.54$ & $5.25 \pm 0.36$ & $5.03 \pm 0.40$ & $4.76 \pm 1.26$ & $4.91 \pm 0.60$ & $4.79 \pm 0.50$ & $3.68 \pm 0.90$ & 3.42 \\
\hline $\mathrm{TiO}_{2}$ & 1.92 & 1.47 & $0.39 \pm 0.10$ & $0.18 \pm 0.07$ & $0.06=0.02$ & $0.13 \neq 0.09$ & $0.32 \pm 0.23$ & $0.40 \pm 0.25$ & $0.80 \pm 0.42$ & 1.18 \\
\hline $\mathrm{P}_{2} \mathrm{O}_{5}$ & & & & & & & & $0.17 \pm 0.10$ & $0.17 \pm 0.14$ & 0.58 \\
\hline $\mathrm{MnO}$ & 0.17 & 0.19 & & & & & & $0.09 \pm 0.13$ & $0.12 \pm 0.09$ & 0.31 \\
\hline $\mathrm{Rb}$ & 66 & 44 & 260 & 267 & 305 & 201 & (262) & - & - & - \\
\hline Sr & 225 & 216 & 110 & 77 & 20 & 60 & (77) & - & - & - \\
\hline $\mathrm{Ba}$ & 750 & 380 & 650 & 475 & 107 & 350 & (457) & - & - & - \\
\hline $\mathrm{Zr}$ & 290 & 115 & 216 & 170 & 174 & 103 & 166 & & - & - \\
\hline $\mathrm{Pb}$ & 18 & 16 & 30 & 33 & 31 & 23 & (30) & - & - & - \\
\hline $\mathrm{Cu}$ & 13 & 13.5 & 9.9 & 7 & 5 & 9 & (8) & - & - & - \\
\hline V & 200 & 300 & 40 & 13.5 & 2.4 & 14.4 & (23) & - & - & - \\
\hline $\mathrm{Cr}$ & 5 & 28 & 22 & 7.8 & 3.8 & 9.6 & (13.3) & - & - & - \\
\hline $\mathrm{Ni}$ & 3.3 & 9.7 & 8.9 & 3.3 & $<2$ & 3.5 & (5.5) & - & - & - \\
\hline Qtz & 15.8 & 8.9 & $28: 9$ & 31.9 & 32.9 & 37.3 & (31.6) & & & 26.6 \\
\hline Microcline & 6.8 & - & 27.8 (19) & 34.5 (17) & $36.2(22)$ & 30.8 & (31.4) & & & 24.1 \\
\hline Plagioclase & 35.5 & 46.5 & $29.5\left(\mathrm{An}_{27}\right)$ & $27.0\left(\mathrm{An}_{21}\right)$ & $47.0\left(\mathrm{An}_{10}\right)$ & $24.3\left(\mathrm{An}_{19}\right)$ & (27.8) & & & 28.0 \\
\hline Biotite & 8.3 & 11.2 & 9.2 & 4.1 & 1.5 & 3.7 & (5.7) & & & 7.2 \\
\hline Muscovite & - & - & 2.8 & - & - & 2.9 & (1.6) & & & - \\
\hline Hbld & 32.2 & 27.8 & - & - & - & - & - & & & 4.1 \\
\hline Ore & 1.5 & 5.7 & .6 & .3 & .2 & .3 & (.4) & & & 6.2 \\
\hline
\end{tabular}

Note: $A=$ Diorite gabbro associated with Cape Granites (Kolbe, 1966) with mesonorm. B = Diorite gabbro associated with Cape Granites (Kolbe, 1966) with mesonorm. $C=17$ analyses: average coarsely porphyritic Cape Granite (Kolbe, 1966) with mesonorm. D = 9 analyses; average medium-grained Cape Granite (Kolbe, 1966) with mesonorm. E = 8 analyses; average fine-grained Cape Granite (Kolbe, 1966) with mesonorm. $F=6$ analyses; average fine-medium-grained younger intrusives, Cape Granite (Kolbe, 1966) G = Overall average 81 analyses Cape Granite; trace elements and modified Barth mesonorm based on Kolbe's (1966) 40 analyses only. $\mathrm{H}=41$ analyses; average Cape Granite (Scholtz, 1946). I = Average sediments and metasediments intruded by Cape Granite, Walker and Mathias (1946). Includes 6 hornfels, 2 phyllites, 2 migmatites, 4 xenoliths, and 2 shales. J = Average of 4 charnockitic-ademellite porphyries, KeimosKakamas Region, Cape Province (Poldervaart, 1966), and average mode.

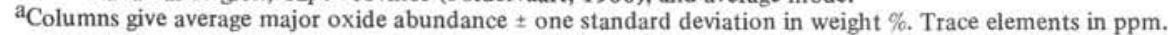

It thus appears that detrital clay results largely from the weathering of Cape Granite or older microclines, and that the transformation of microcline to clays does not result in wholesale changes in alkali-alkali earth ratios. Plagioclases, however, are preferentially weathered, resulting in a net loss of especially $\mathrm{Ca}$ and some $\mathrm{Na}$. $\mathrm{Sr}$ and especially $\mathrm{Ba}$ are not lost with $\mathrm{Ca}$ during weathering of plagioclase because with their smaller ionic radii they are better able to fit in the alkali feldspar structure during the late stages of granitic differentiation, and alkali feldspar was not preferentially weathered.

These considerations imply that weathering conditions permitted $\mathrm{K}, \mathrm{Rb}, \mathrm{Ba}$, and $\mathrm{Sr}$ to remain in soils during and after transformation of feldspars to clays. The soils were therefore probably not developed under damp climatic conditions with extensive vegetative cover. This would have produced low soil $p \mathrm{H}$, because of formation of carbonic acid as organic material decomposed, and this in turn would have stripped alkalis and alkali earths from the weathering zone with any major rainfall. A more arid soil, with less chance for organic material to decompose, is indicated. Illite is known to be abundant in soils of arid regions (E. Knox, cited in Grim, 1964). Chermozem soils, in particular, are illitic soils found in areas of 12-25 inches of rainfall in cool climates. They develop thick black A soil horizons rich in organic matter under an extensive grass cover. MacLachlan and Pieterse (this volume) argue that the dominant Classopolis-pollen in Unit 7 sediments has such limited diversity that a harsh (dry and/or cold) climate existed. They cite Hughes (1973) who concluded that plants producing Classopolis pollen were coniferophytes that grew on the seaward side of deltas as mangrove plants do today. If we take this analogy literally, then the Classopolis-pollen-producing plants may have grown in effectively swampy conditions, perhaps in a few feet of water. Pollen from ferns, which may have filled the role of grasses during the Cretaceous, and from fungi, are rare in Unit 7 sediments, possibly swamped by the abundant Classopolis. This may simply have been the result of concentration of Classopolis-pollen-producing plants at the mouths and along the banks of rivers. We have already inferred a virtually direct link between Unit 7 sediments at Site 361 to mouths of Cretaceous rivers, with little or no shelf or slope residence time.

In lagoonal sediments, illite is the dominant clay (Grim, 1964). Standing water in a swampy environment should inhibit oxidation of organic matter in muds as well as the leaching of clays. Thus a cold, fairly dry climate should have promoted chermozem-type soils in valleys and other high-standing areas in the rugged high-latitude Cape Mountains of that time. Lagoons may have been common because of (1) rapid regional subsidence due to lithospheric cooling (Melguen, this volume), and (2) local subsidence and tilting of fault blocks produced during rifting (Siesser, this volume). Clays brought down from highland soils and trapped for any length of time in lagoons would not have been 
TABLE 3

Mineral Data, Cape Granites (From Kolbe, 1966)

\begin{tabular}{|c|c|c|c|c|c|c|c|c|}
\hline & \multicolumn{4}{|c|}{ Microclines } & \multicolumn{2}{|c|}{ Plagioclases } & \multirow{2}{*}{$\begin{array}{c}\text { Biotite } \\
7\end{array}$} & \\
\hline & 1 & 2 & 3 & 4 & 5 & 6 & & \\
\hline \multicolumn{9}{|c|}{ Major Elements (wt \%) } \\
\hline $\mathrm{SiO}_{2}$ & $(64.88)$ & $(65.20)$ & $(64.43)$ & $(64.86)$ & $(63.06)$ & $(62.77)$ & - & \\
\hline $\mathrm{Al}_{2} \mathrm{O}_{3}$ & (18.71) & $* 18.74)$ & $(18.51)$ & (18.67) & $(22.69)$ & $(22.94)$ & - & Data in weight $\%$ \\
\hline $\mathrm{FeO}^{*}$ & 0.06 & 0.06 & 0.07 & $(0.06)$ & 0.15 & 0.30 & 21.54 & \\
\hline $\mathrm{MgO}$ & 0.01 & 0.01 & 0.01 & $(0.01)$ & 0.11 & 0.09 & 7.89 & \\
\hline $\mathrm{CaO}$ & 0.22 & 0.19 & 0.22 & $(0.21)$ & 3.99 & 4.27 & 0.66 & \\
\hline $\mathrm{Na}_{2} \mathrm{O}$ & 2.38 & 1.89 & 2.21 & $(2.21)$ & 7.82 & 7.76 & 0.19 & \\
\hline $\mathrm{K}_{2} \mathrm{O}$ & 13.12 & 13.96 & 13.27 & (13.38) & 2.36 & 2.22 & 8.11 & \\
\hline $\mathrm{TiO}_{2}$ & 0.01 & 0.00 & 0.00 & $(0.00)$ & 0.03 & 0.04 & 3.30 & \\
\hline \multicolumn{9}{|c|}{ Trace Elements (ppm) } \\
\hline $\mathrm{Rb}$ & 412 & 543 & 642 & (501) & 71 & 83 & 1012 & \\
\hline $\mathrm{Sr}$ & 166 & 94 & 44 & (118) & 157 & 112 & 6.2 & \\
\hline $\mathrm{Ba}$ & 1609 & 1006 & 230 & (1124) & 265 & 161 & 655 & \\
\hline $\mathrm{Zr}$ & $<10$ & 12 & $<10$ & $<10$ & $\sim 100$ & $\sim 120$ & 130 & \\
\hline $\mathrm{Pb}$ & 41 & 34 & 28 & (36) & 26 & 17 & 21 & \\
\hline $\mathrm{Cu}$ & 2.3 & 2.1 & 2.1 & $(2.2)$ & 18 & 6 & 15 & \\
\hline V & - & - & - & - & $<2$ & $<2$ & 2600 & \\
\hline $\mathrm{Cr}$ & - & - & - & - & - & - & 150 & \\
\hline $\mathrm{Ni}$ & - & - & - & - & - & - & 61 & \\
\hline
\end{tabular}

Note: $1=$ Average microcline from coarsely porphyritic Cape Granites. $2=$ Average microcline from mediumgrained Cape Granites. 3 = Average microcline from fine-grained Cape Granites. 4 = Average microcline from all above Cape Granites, weighted to number of analyses of each type of granite. 5, 6 = Plagioclases from coarsely porphyritic Cape Granites (main stage). $\mathrm{SiO}_{2}$ and $\mathrm{Al}_{2} \mathrm{O}_{3}$ for Columns 1-6 calculated from end member $\mathrm{KAlSi}_{3} \mathrm{O}_{8}, \mathrm{NaAlSi}_{3} \mathrm{O}_{8}$, and $\mathrm{CaAl}_{2} \mathrm{Si}_{2} \mathrm{O}_{8}$ compositions given initial $\mathrm{K}_{2} \mathrm{O}, \mathrm{Na}_{2} \mathrm{O}$, and $\mathrm{CaO} . \mathrm{Fe}_{3} \mathrm{O}$ and $\mathrm{MgO}$ were neglected in these calculations. 7 = Biotite from coarsely porphyritic Cape Granite.

modified significantly, and could have acquired the coarse and abundant plant material recovered at Site 361 by passing through such forested swampy areas. Most of the wood chips in Unit 7 sandstones are well rounded, resembling the wood "chaff" abundant in the sands of modern beaches adjacent to forested regions.

We thus have a composite of information pointing to a cool, dry climate in southern Africa during the Aptian. Highland regions developed extensive illitic soils, probably under a dense mat of low vegetation, and lowlands were swampy and forested.

Figure 12 demonstrates that Unit 7 sediments are enriched in $\mathrm{Zn}, \mathrm{V}, \mathrm{Ni}$, and to a lesser extent, $\mathrm{Cu}, \mathrm{Cr}, \mathrm{Pb}$, and $\mathrm{Mn}$ with respect to potential source rocks. These elements and total organic carbon are plotted versus $\mathrm{TiO}_{2}$ which is a useful oxide to discriminate potential source rocks (e.g., basalts versus granites) and one which is sensitive to the process of concentration of quartz during the formation of sandstone. From Figure 12 , there is clearly a strong correlation of these transition metals with organic carbon. The sandstones contain lower transition-metal abundances than the one shale analyzed, the result of "dilution" of the carbonaceous shaley component in the sandstones with quartz.

The transition metal abundances in the shale (Section 361-48-1) are similar to those of typical black shales (Vine and Tourtelot, 1970) as shown in Table 4. There is the same general correlation with organic carbon, although $\mathrm{Pb}$ seems a bit higher and $\mathrm{Ni}$ and $\mathrm{Cr}$ lower than in the median black shale of Vine and Tourtelot, but there is no extreme enrichment of metals relative to organic carbon that would suggest an unusual seawater composition. Baker et al. (this volume) report the occurrence of nickel, vanadyl, and free-base porphyrins in separates of organic material from Unit 7 sediments. Chelation of metals onto organic compounds during biological processes is more pronounced in seawater than fresh water, and produces notable enrichments of $\mathrm{V}$ in particular (Goldberg, 1957). Porphyrins are derivatives of chlorophyll, the green coloring material of plants, and the characteristics of nickel, vanadyl, zinc, and free-base porphyrins reflect the diagenetic history of organic material in sediments (Baker et al., this volume). In sediments where both abundant marine nannoflora and terrestrial plant material were being deposited, the enrichments in $\mathrm{V}$ and the other transition metals is no surprise. There appears to have been no diagenetic or epigenetic enrichment of metals in the organic material that would indicate, say, the presence of sea-floor hydrothermally heated and metalenriched bottom waters or formation waters. But the porphyrins do appear to indicate mixture of "reworked thermally stressed or oxidized terrestrial material into a population of porphyrins with a mild thermal history" (Baker et al., this volume). MacLachlan and Pieterse (this volume) noted the presence of darkened miospores with high thermal alteration indices (2.5-orange, to 4-brown-black). This variable darkening occurred on common species, but there were no darkened phytoplankton. They suggested that the darker miospores were the result of forest fires. These two studies appear 


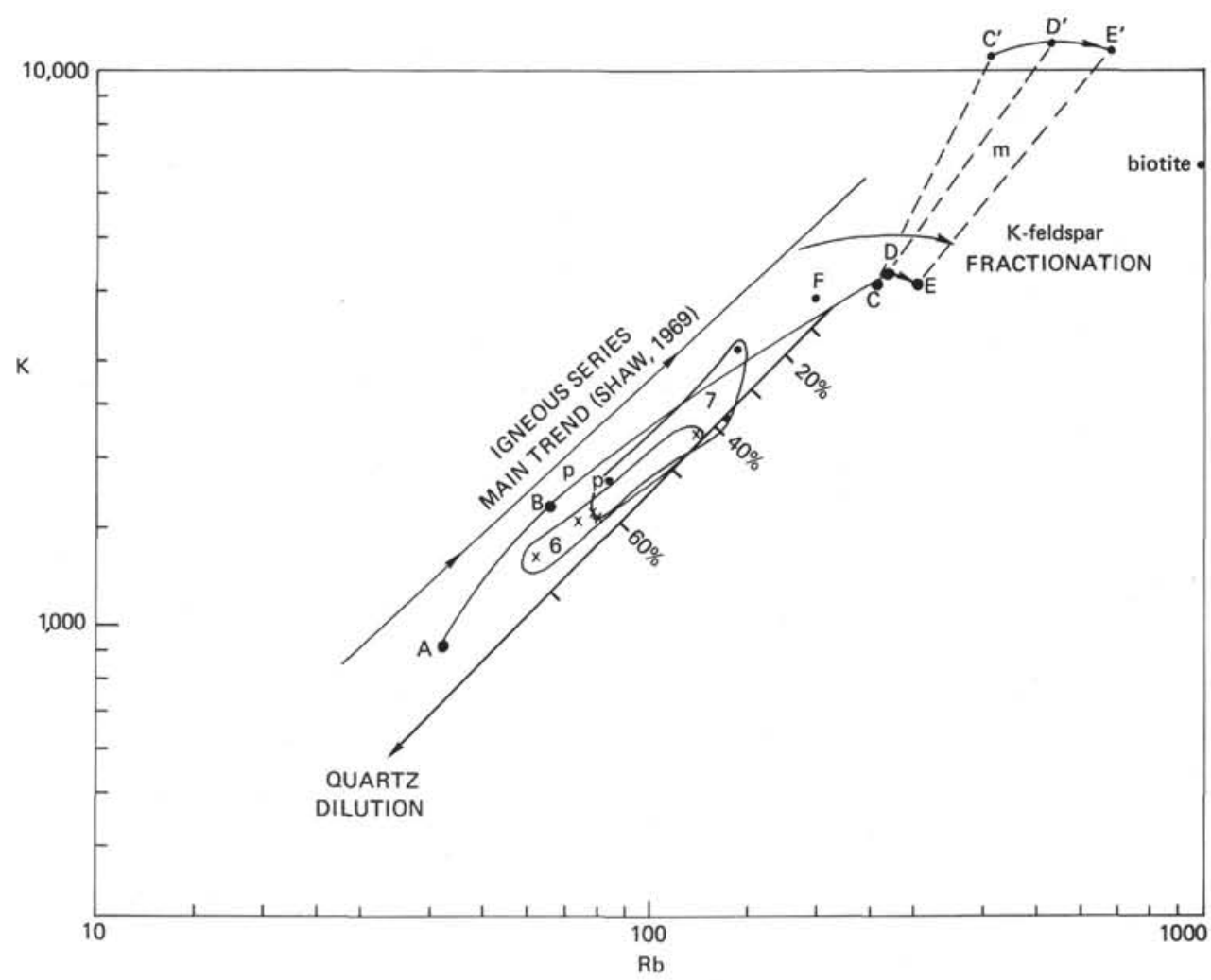

Figure 7. $\log K$ versus $L o g R b$ for Site 361 sediments. Points $A, B, C, D, E$, and $F$ are from Columns $A-F$ of Table 2. $C^{\prime}, D^{\prime}$, and $E^{\prime}$ are from Columns 1-3 of Table 3, representing $K$-feldspar compositions for the three increasingly fractionated stages of Cape Granite evolution, given by Columns $C$-E of Table 2. Points $p, m$, and $b$ are for Plagioclase muscovite and biotite compositions ( $p$ and $b$ given in Table 3) from Kolbe (1966). The Main-Trend line from Shaw (1969) illustrates the general covariance of magmatic differentiation sequences basalt-trachyte, basalt-rhyolite, etc. The transition from Cape gabbro-diorites to Cape Granites parallels this trend, but the sharp increase in $R b$ relative to $K$ among the granites requires $K$-feldspar fractionation (Kolbe, 1966). The Unit 7 sediments have lower $K / R b$ than the gabbro-diorites $(A, B)$ because of their primarily granitic source, but both $K$ and $R b$ have been "diluted" by mechanical concentration of quartz during sediment transport. The proportion of quartz dilution can be gaged approximately from the quartz dilution scale on the diagram (note that it is logarithmic).

to have uncovered evidence for the same phenomenon. If the inference about forest fires is correct, we have still another bit of evidence for a dry climate in southern Africa during the Aptian.

\section{Unit 6}

Figures 6-11 reveal several major differences between Unit 6 and Unit 7 compositions. These are

1) A higher amount of montmorillonite in the Unit 6 claystones (Figure 6, see also Siesser and Bremner, this volume), and apparently of mafic mineral and rock fragments in the siltśtone. As discussed earlier, the montmorillonite implies a more mafic source and has now become mostly mixed-layer smectite-illite during diagenesis.

2) Among the three Unit 6 claystones, there is no coherence among $\mathrm{K}, \mathrm{Rb}, \mathrm{Ba}$, and $\mathrm{Sr}$ (Figures 7-10), probably because of a longer residence time in seawater than the extremely rapidly deposited clays of the Unit 7 turbidites.
3) The $\mathrm{K}, \mathrm{Rb}, \mathrm{Ba}$, and $\mathrm{Sr}$ of the siltstone, however, should not have been affected by this and thus should more closely reflect the original composition of the non-quartz components of the rock. These are mostly fresh to altered mineral and rock grains in what was originally most likely nearly clay-free sediment. Following the same arguments used for Unit 7, Figures 7-10 suggest that the siltstone non-quartz component has roughly an andesitic to dioritic composition, and that this has been diluted by about $20 \%-30 \%$ by mechanically concentrated quartz.

3) Unit 6 is higher in transition metals, especially $\mathrm{Ni}$ and $\mathrm{Cr}$, than Unit 7. But these metals are not associated with organic carbon. On the other hand, $\mathrm{MnO}, \mathrm{Cu}, \mathrm{Ni}$, and $\mathrm{Zn}$ are too low for the two red clays analyzed to be pelagic clays. Ichthyoliths (fish debris) are also rare or absent, although both manganese oxide micronodules and ichthyoliths are abundant in Unit 5, which we do consider a pelagic clay (Chapter 2, this volume; Doyle et al., this volume). Concentration of manganese oxides 


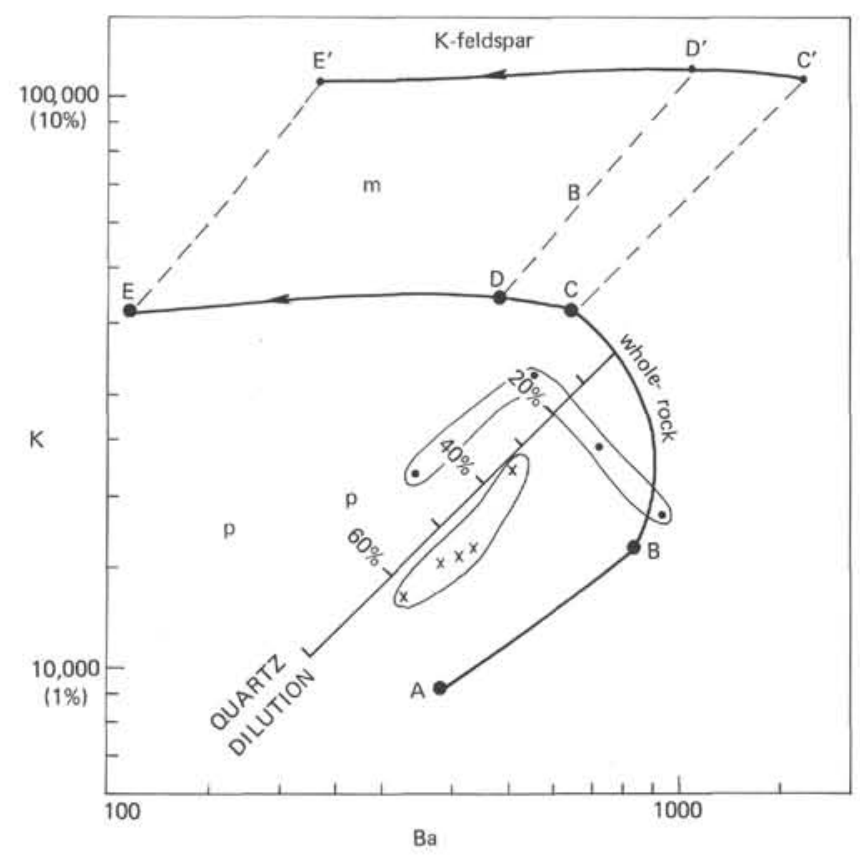

Figure 8. Log-log, $\mathrm{K}$-Ba diagram. Letters and symbols as in Figure 7. Tie lines connect Cape Granite whole-rock and $K$-feldspar compositions. Quartz-dilution scale indicates 60\% dilution for Unit 7 sandstones and points to an average source composition slightly less fractionated than main-stage Cape Granites. Three Unit 6 sediments have as high or higher $K / B a, K / S r, R b / B a$, and $R b / S r$ than Unit 7 sediments. All are claystones and presumably had $K$ and $R b$ enhanced by interaction of clays with seawater. Only the Unit 6 siltstones have $K, R b, B a$, and $\mathrm{Sr}$ reflecting primary sources, which appears to have been closer to andesitic than granitic compositions.

and ichthyoliths in pelagic clays requires extremely low sedimentation rates (Arrhenius, 1963). Their absence in Unit 6 red clays implies a higher sedimentation rate than pelagic clays, hence I conclude that they had a terrigenous source. Transition metal abundances, though, are high enough to imply a significant mafic component in all Unit 6 sediments analyzed. The high $\mathrm{Ni}$ and $\mathrm{Cr}$ especially suggest a basaltic provenance.

Figure 13 is a plot of atomic Ti versus Al. High Ti, of course, characterizes basalts, and is therefore one of the most useful indicators of basaltic provenance. Boström et al. (1972) concluded that sediments with $\mathrm{Ti} / \mathrm{Al}$ of 0.039 or greater have a basaltic volcanic component. On Figure 13, a line is drawn indicating this ratio. All Unit 6 sediments fall closer to this line than Unit 7 sediments (the lowest $\mathrm{Ti} / \mathrm{Al}$ in the Unit 6 sediments analyzed is 0.032 ) and one falls well above it $(\mathrm{Ti} / \mathrm{Al}=0.05)$.

It is perhaps more useful to take into account possible variations in $\mathrm{Ti}$ among potentially contributing basalts, and to estimate what proportion of a given sediment they might be. A useful range in $\mathrm{Ti}$ is that between average oceanic tholeiite basalt, at the low end, and average alkalic olivine basalt at the high end (Engel et al., 1965), both plotted on Figure 13. Also

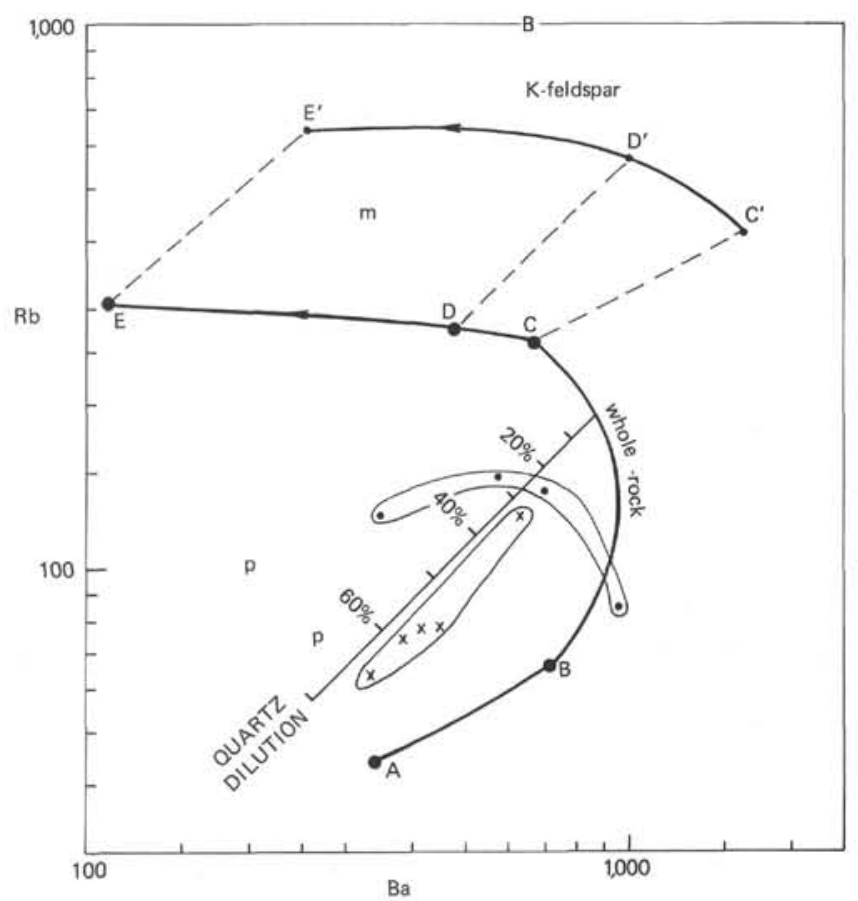

Figure 9. Log-log, $R b$-Ba, diagram. Letters and symbols as in Figure 7. Tie lines connect Cape Granite whole-rock and $K$-feldspar compositions. Quartz-dilution scale indicates $60 \%$ dilution for Unit 7 sandstones and points to an average source composition slightly less fractionated than main-stage Cape Granites. Three Unit 6 sediments have as high or higher $\mathrm{K} / \mathrm{Ba}, \mathrm{K} / \mathrm{Sr}, \mathrm{Rb} / \mathrm{Ba}$, and $\mathrm{Rb} / \mathrm{Sr}$ than Unit 7 sediments. All are claystones and presumably had $K$ and $R b$ enhanced by interaction of clays with seawater. Only the Unit 6 siltstones have $K, R b, B a$, and $S r$ reflecting primary sources, which appears to have been closer to andesitic than granitic compositions.

shown are points for average shale (Clarke, 1924), average rhyolite (Daly, 1933), and average Cape Granite (Kolbe, 1966). A quartz dilution control line from the average shale passes through four of the five Unit 7 compositions and is very close to the average Cape Granite. There is thus no detectable basaltic component in Unit 7 sandstones or the Unit 7 shale.

Unit 6 sediments, though, may have at least $15 \%$ and as much as $65 \%$ average oceanic tholeiite, or between $8 \%$ and $50 \%$ continental tholeiite. Some andesites could explain the higher $\mathrm{Ti}$ in Unit 6 sediments, but they could not explain the high $\mathrm{Ni}$ and $\mathrm{Cr}$ in two of them.

In summary, there is clear chemical evidence for a probable basaltic component to Unit 6 claystones that is not evident in Unit 7. Andesite or diorite compositions are reflected in the alkali and alkali earth ratios of the Unit 6 siltstone, but it has higher $\mathrm{Ni}$ and $\mathrm{Cr}$ than such rocks, reflecting some basaltic input as well. The basalt alkalis and alkali-earths ratios would have been similar to those of andesites or diorites. Basalt therefore would have acted mainly as a dilutant on these elements, one much less effective than quartz on Figues 7-10. The alkali-alkali-earth ratios thus should resemble andesites, and the trace transition metals resemble basalts. 


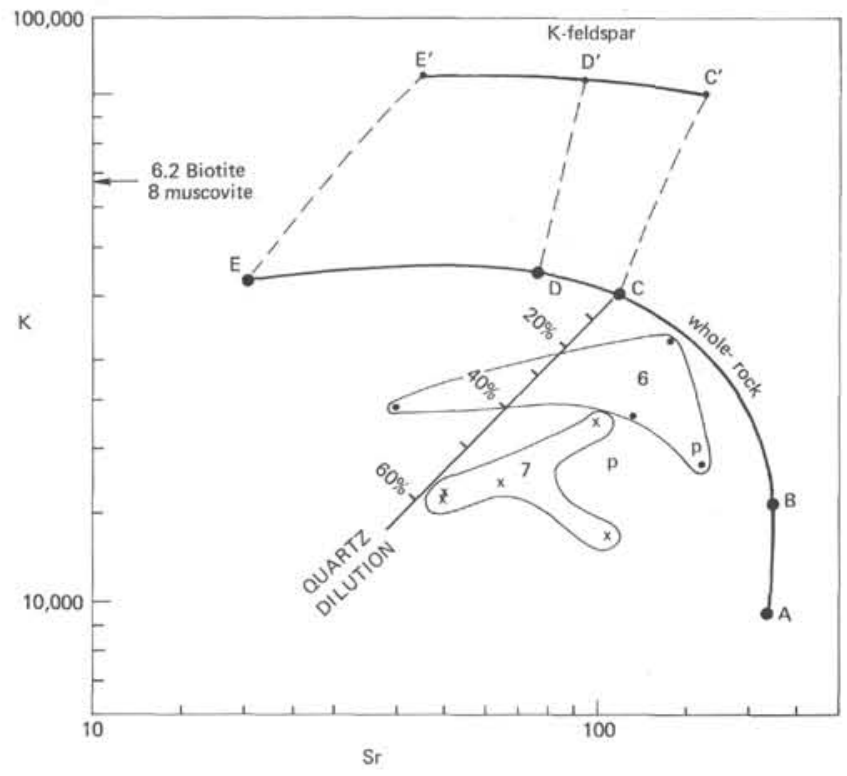

Figure 10. Log-log, and diagram. Letters and symbols as in Figure 7. Tie lines connect Cape Granite whole-rock and $K$-feldspar compositions. Quartz-dilution scale indicates $60 \%$ dilution for Unit 7 sandstones and points to an average source composition slightly less fractionated than main-stage Cape Granites. Three Unit 6 sediments have as high or higher $K / B a, K / S r, R b / B a$, and $R b / S r$ than Unit 7 sediments. All are claystones and presumably had $K$ and $R b$ enhanced by interaction of clays with seawater. Only the Unit 6 siltstones have $K, R b, B a$, and $S r$ reflecting primary sources, which appears to have been closer to andesitic than granitic compositions.

Along the western coast of southern Africa, only the Orange River drains basaltic and andesitic terrane. The basalts are the Karroo basalts of the South African interior (Haughton, 1969). Andesites are exposed in the Kheis terrane in Namaqualand (Kröner, 1974). The Orange River is the largest river along this part of the African coast, the only one which has incised the great escarpment, and is known to have existed in the Cretaceous (Dingle and Scrutton, 1974). I thus infer that the basaltic and andesitic provenance of Unit 6 reflects input from the Orange River. The increase in palynomorph diversity between Cores $22-24$ and 27 of Unit 6 also appears to require a more northerly and temperate source (MacLachlan and Pieterse, this volume). I argue that this change in provenance coincided with the development of vigorous circulation in the Cape Basin, and that specifically a deep current of dense water flowed south across the Orange River delta transporting sediments from there to Site 361 . Unlike the North Atlantic Western Boundary Undercurrent, this one flowed from low to high latitudes, hence was warm, not cold, and dense because of salinity, not low temperature.

\section{AUTHIGENIC MINERALS IN UNIT 7 SANDSTONES}

Siesser and Bremner (this volume) report phillipsite to be a minor but ubiquitous mineral in the Unit 7

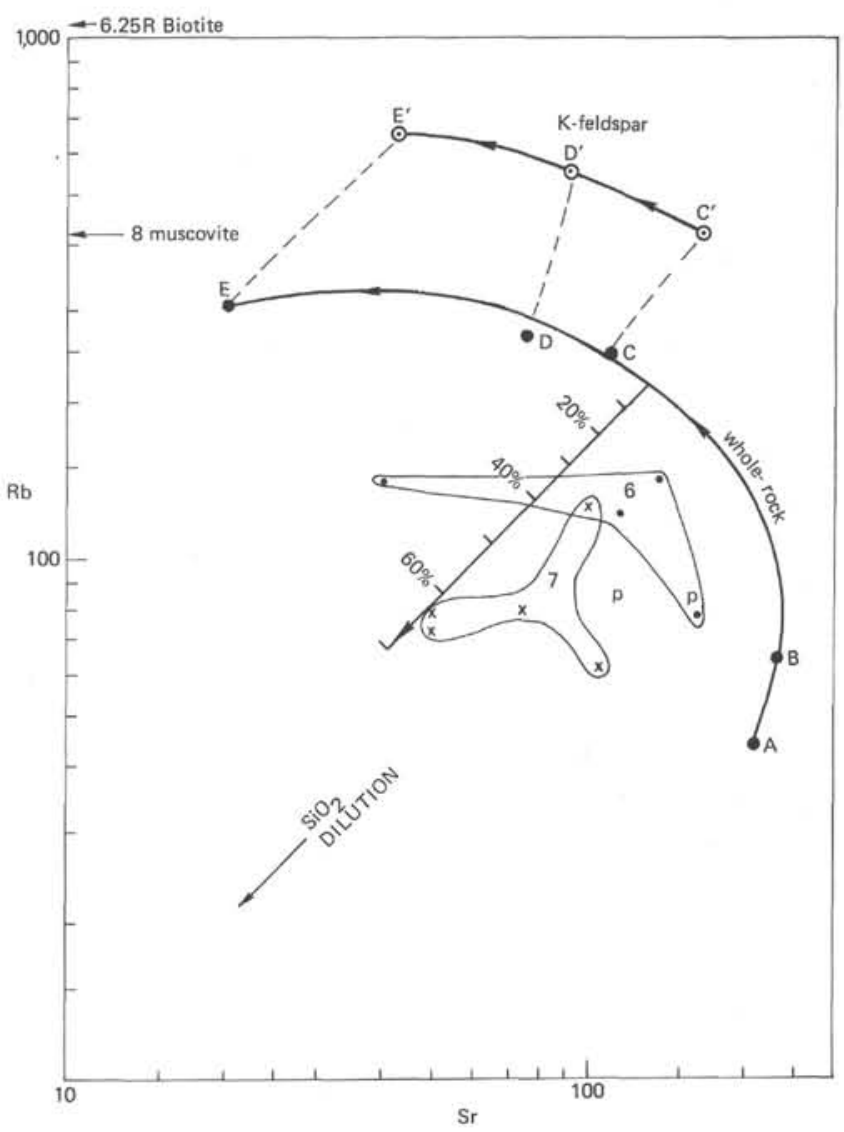

Figure 11. Log-log, Rb-Sr diagram. Letters and symbols as in Figure 7. Tie lines connect Cape Granite whole-rock and $K$-feldspar compositions. Quartz-dilution scale indicates $60 \%$ dilution for Unit 7 sandstones and points to an average source composition slightly less fractionated than main-stage Cape Granites. Three Unit 6 sediments have as high or higher $K / B a, K / S r, R b / B a$, and $\mathrm{Rb} / \mathrm{Sr}$ than Unit 7 sediments. All are claystones and presumably had $K$ and $R b$ enhanced by interaction of clays with seawater. Only the Unit 6 siltstones have $K, R b, B a$, and $S r$ reflecting primary sources, which appears to have been closer to andesitic than granitic compositions.

sandstones of Site 361 . It is widely considered that basalt is the most common precursor of phillipsite in marine sediments (Hay, 1966; Stonecipher, 1976b). A host of evidence already discussed, however, indicates that basalt is not a contributor to Unit 7 sandstones. Stonecipher (1976a) has found that clinoptilolite, not phillipsite, characterizes sediments with $\mathrm{Ti} / \mathrm{Al}$ less than 0.030 . These include terrigenous sandstones. Among the four Unit 7 sandstones analyzed, the highest $\mathrm{Ti} / \mathrm{Al}$ is 0.0285 . Even in sediments with a significant basaltic component, Stonecipher (1976b) reports phillipsite does not occur in sediments cored by DSDP older than Eocene, nor in sediments with more than 1000 meters overburden. Unit 7 is both older (by almost a factor of two) and buried more deeply than this. One cannot plead that Unit 7 is special because it has abundant organic carbon. Sediments studied by Stonecipher (1976a) from DSDP Site 105 in the North Atlantic are clinoptilolite-bearing (even rich) 


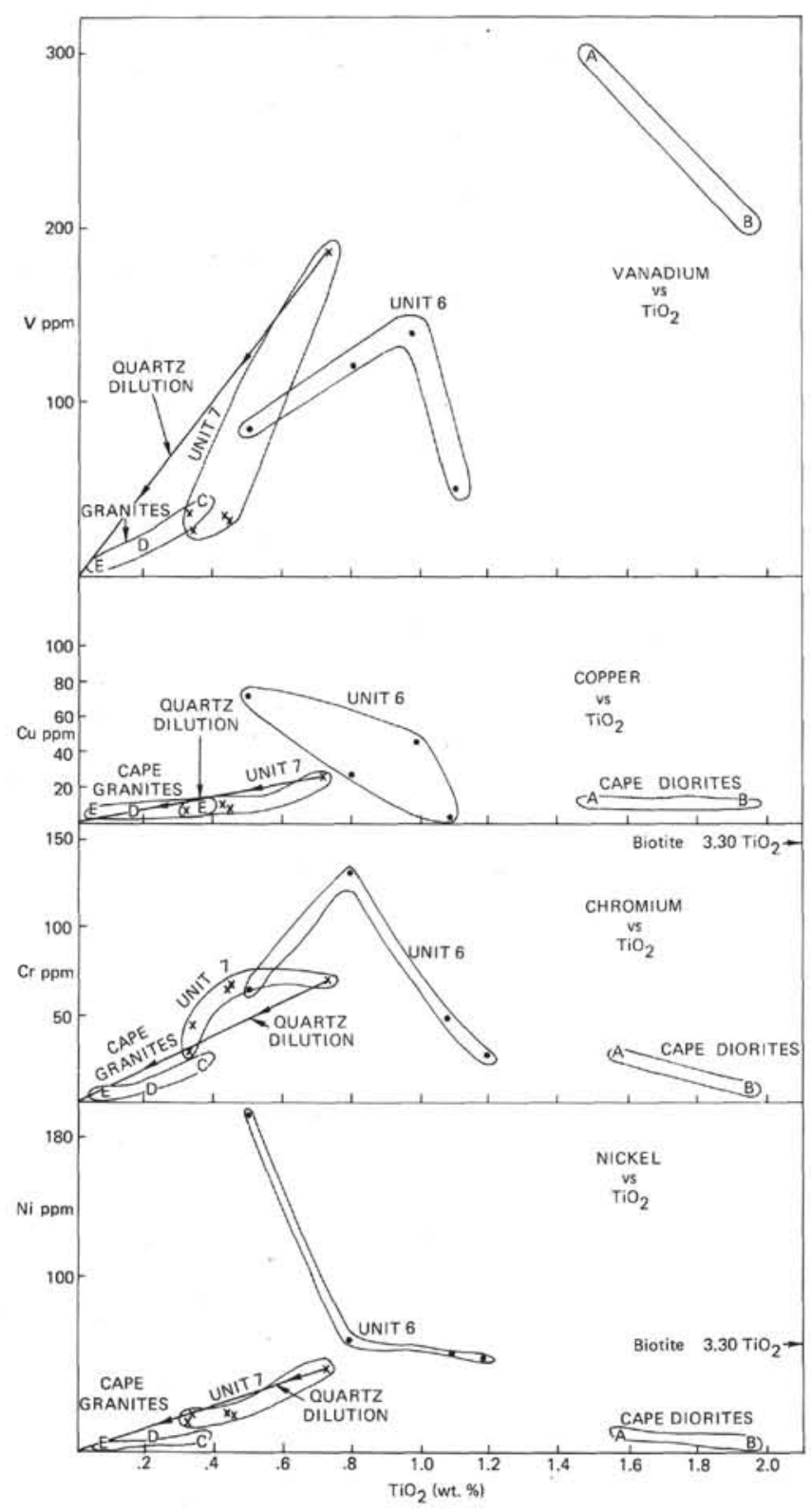

Figure 12. Variation diagrams of trace transition metals versus $\mathrm{TiO}_{2}$. Points $A-E$ correspond to Columns $A-E$ of Table 2, in that order. Quartz dilution control lines are drawn from the Unit 7 shale points (40-361-41-1, $7-11 \mathrm{~cm})$ to the origins. Since the remaining Unit 7 sandstones have experienced about $60 \%$ dilution relative to Cape Granites by mechanical concentration of quartz, their "undiluted" abundances of these elements must be far higher than in any of their major source rocks.

Cretaceous carbonaceous shales of similar major element composition to Unit 7 shales. Carbonaceous sediments at Site 330 on the Falkland Plateau have a strongly granitic provenance, are the same age as Unit 7 sandstones (Aptian), and were deposited at shallow levels within the same anoxic water mass that filled the Cape Basin. Yet they, too, contain clinoptilolite, not phillipsite (Thompson, 1977).

Hay (1966) has pointed to the common occurrence of phillipsite in altered tuffs in saline lakes and argues that
TABLE 4

Trace Element and Carbon Content of Unit 7 Shale Compared With Median Black Shale (MBS) of Vine and Tourtelot (1970)

\begin{tabular}{lrr}
\hline & & $\begin{array}{c}361-48-2, \\
\text { MBS }^{\mathrm{a}}\end{array}$ \\
\hline $\mathrm{C}_{\text {org }}$ & $3.2 \%$ & $3.99 \%$ \\
$\mathrm{Sr}$ & $200 \mathrm{ppm}$ & $100 \mathrm{ppm}$ \\
$\mathrm{Ba}$ & $300 \mathrm{ppm}$ & $507 \mathrm{ppm}$ \\
$\mathrm{Zr}$ & $70 \mathrm{ppm}$ & $394 \mathrm{ppm}$ \\
$\mathrm{Cu}$ & $70 \mathrm{ppm}$ & $25 \mathrm{ppm}$ \\
$\mathrm{Ni}$ & $50 \mathrm{ppm}$ & $48 \mathrm{ppm}$ \\
$\mathrm{Zn}$ & $<300 \mathrm{ppm}$ & $302 \mathrm{ppm}$ \\
$\mathrm{Pb}$ & $20 \mathrm{ppm}$ & $41 \mathrm{ppm}$ \\
$\mathrm{V}$ & $150 \mathrm{ppm}$ & $185 \mathrm{ppm}$ \\
$\mathrm{Cr}$ & $100 \mathrm{ppm}$ & $68 \mathrm{ppm}$ \\
\hline aTrace element data cited to near- \\
est 10 ppm.
\end{tabular}

it forms from the breakdown of siliceous glass at high salinities and a $p \mathrm{H}$ of 9 or more. The high salinities apparently reduce the activity of silica in the pore fluids, favoring formation of phillipsite over the more siliceous clinoptilolite. The high $p \mathrm{H}$ is the result of hydrolysis of glass. Hay notes that phillipsite forms in quartz sandstones in some of the same saline lakes containing the zeolitic tuffs he has studied, but is somewhat less certain about the conditions of zeolite formation. Zeolites of various types can apparently form by breakdown of primary silicate minerals and phyllosilicates by a mechanism similar to the breakdown of glass. Salinity and $p \mathrm{H}$ are still high, but primary minerals, especially quartz, are less liable to attack by saline brines than volcanic glass, and silica activity is consequently reduced.

To examine the problem further, I used a Scanning Electron Microscope to look at individual mineral grains, lithic grains, and cemented clumps hand-picked from coarse fractions $(>63 \mu \mathrm{m})$ of several Unit 7 claycemented sandstones. X-ray diffraction patterns of powders from the cemented clumps revealed the presence of illite, kaolinite, and phillipsite, in addition to primary quartz, K-feldspar, and plagioclase. Authigenic K-feldspar may have been present, but was masked by peaks from detrital $\mathrm{K}$-feldspar and other minerals.

When viewed with the Scanning Electron Microscope, lithic grains present only an appearance of poorly structured, sometimes slightly foliated densely packed clays, or of well-crystallized quartz (Plate 5, Figure 1). The composite cemented clumps are more instructive. These are composed of quartz, plagioclase, and $\mathrm{K}$-feldspar grains cemented by various clays. Photographs taken of these grains reveal extensive solution features on quartz and feldspar grains, and the habit of authigenic minerals cementing the clumps together.

Both quartz and $\mathrm{K}$-feldspar grains show extensive solution etching. Quartz crystals in lithic grains (quartzite) show tiny V-shaped or orthogonal notches on termination crystal faces (Plate 5, Figure 1). Margolis (1968) and Tankard and Krinsley (1974) 


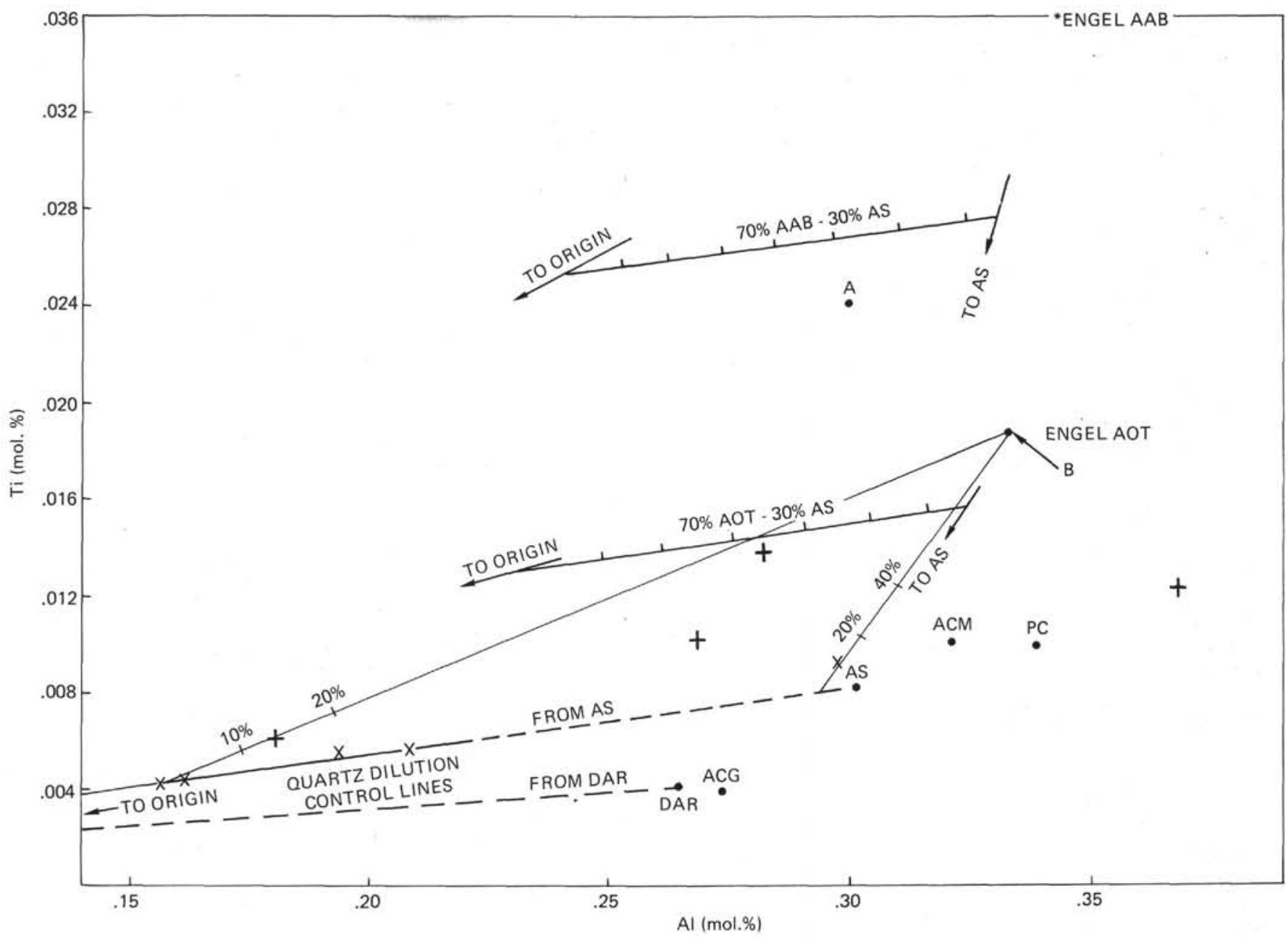

Figure 13. Ti versus $\mathrm{Al}$ (mol \%) for Units 6 and 7 sediments, after Stonecipher (1976a). X's are Unit 7, +'s Unit 6 sediments. Engel $A A B=$ Engel et al. (1965) average alkalic basalt, Engel AOT = Engel et al. (1965) average oceanic tholeiitic. AS is average shale of Clark (1924). PC is pelagic clay composition from Hughes (1969). DAR is Daly's (1933) average rhyolite. $A C G$ and ACM are average Cape Granite and average Cape metasediment, respectively (from Table 2). $A$ and $B$ are gabbrodiorites from Table 2. Quartz dilution control lines are drawn from AS and DAR to origin. Mixing lines are drawn through two Unit 7 compositions (most quartzose and least quartzose) between dilution line from AS and Engel AOT. Percentages along these mixing lines suggest how little AOT, $A, B$, or AAB can be in Unit 7 sediments. Hachured lines indicate locus of compositions of any quartz dilution wherein the remaining portion of the sediment is $30 \%$ AS and $70 \%$ AOT or AAB, respectively.

argue that cleavage direction is important in controlling the geometry of etch patterns on quartz, noting especially parallel solution grooves which they say form along cleavage planes. The quartz grain in the upperleft corner of Plate 5, Figure 2, shows parallel etching on its extreme upper edge and an extensively developed notch-like pattern on its other larger surface (toward the center of the photograph). This surface is sharply oblique to the upper edge with the parallel etching. The entire grain, in fact, resembles a truncated stack of rods extending into the picture from the upper left. Both parallel grooves and $\mathrm{V}$-shaped notches thus appear to be controlled crystallographically and are different views of the same phenomenon, or more precisely, they are views of solution features on surfaces nearly paralleling different crystal faces.

The most typical form of quartz grain etching is pictured in Plate 5, Figure 3. Over a dozen grains hand picked from several samples showed similar surface features, with poor crystallographic control on the etch pattern resulting in a blocky, chaotic type of surface morphology. Flaking, and even incipient parting or formation of cleavage plates is evident. The general lack of crystallographic control suggests that the dissolving solutions were of such strength that differences in surface-free energies were not sufficient to focus attack in specific crystallographic directions.

$\mathrm{K}$-feldspar exhibits more spectacular crystallographic control on solution features than quartz. It is also partially transformed to the aluminous clay, kaolinite (Plate 5, Figure 4). Solution was concentrated along the $\mathrm{K}$-rich layers in the feldspar structure, leaving the aluminous layers as prominent parallel ridges. Hydration then altered the exposed ridges to clays, in some places bonding them together in parallel stacks or bundles of dickite, a kaolinite polymorph. Complexes 
of potassium silicate dissolved from between the aluminum silicate ridges, and combined with dissolved silica from quartz to form the abundant illite (K-mica) cementing the sandstones. In the case of both kaolinite, and illite, then, as little modification of the K-feldspar structure occurred as necessary to form the clays. Dickite bundles of the type pictured in Plate 5, Figure 1 , resulted not only from general solution of entire surfaces of $\mathrm{K}$-feldspar grains, but also from concentrated action in solution pits or fractures (Plate 5 , Figures 5 and 6). Here crystallographic control on the growth of kaolinite plates is also evident.

Whether solution of quartz occurs along cleavage planes or not, there is no doubt that feldspar is susceptible to solution along cleavage planes. This appears to be especially so for plagioclase. The grain in Plate 5, Figure 7 is flaking moderately over its entire surface, which appears to be altering to clays. Individual cleavage plates are also coated with clays. The prominent development of cleavage plates on this grain may have been accelerated by expansion of clays growing in solution grooves.

The clays cementing the sandstones take several forms. X-ray diffraction is sufficient only to group these together as illite. Quartz grains can be plastered with thin, curled plates having irregular edges resembling untrimmed, freshly rolled pie crust dough (Plate 6, Figure 1). Other grains are coated with thick, puffy-looking clay layers (Plate 6, Figures 2 and 3). Still other grains are thinly coated not with plates, but with what is almost a shell of either calcite, amorphous clay, or silica (Plate 6, Figure 4). Most clays associated with carbonaceous material are highly amorphous in appearance, and perhaps include organic compounds in their structure. The one well-structured clay found coating carbonaceous material is halloysite, another kaolinite polymorph. In Plate 6, Figures 5 and 6 , it exhibits its typical bent-tube habit. The tubes appear to "uncurl" from central stacks which structurally are probably very similar to the dickite bundle of Plate 5, Figure 2.

Authigenic minerals other than clays were hard to find, probably because they are typically heavily coated with clays. A probable phillipsite termination can be seen in the lower-right corner of Plate 5, Figure 2, peeking from a mass of poorly structured clay. Similar terminations reach through the shell-like coating in Plate 6, Figure 4. The large grain in the upper center of this picture resembles a feldspar grain, but this could not be verified with the dispersive X-ray analyzer attached to the SEM because the grain is completely coated with the shell-like material.

The mechanism of growth of authigenic minerals in these sandstones resembles that described by Divis and McKenzie (1975) who subjected quartz-feldspar sands to hydrothermal conditions in brines of various compositions in sealed capsules at pressures up to 3 kbar and temperatures up to $300^{\circ} \mathrm{C}$. They were able to grow authigenic phyllosilicates and analcime in Na-rich brines. Both the clays, which were found to be varieties of illites by electron diffraction techniques, and the analcime, appeared to make use of tetrahedral groups of the feldspar structure as a basis for their own crystal structure, thus minimizing structural disruption and breaking of bonds, a mechanism predicted by DeVore (1967). Solution pits and etch features were evident on many quartz and feldspar grains. The extensively attacked quartz, detrital K-feldspars, and other minerals in the Unit 7 sandstones are more extreme versions of the features described by Divis and McKenzie. The structural control of the feldspar lattice on the formation of kaolinite (as a residual mineral) and illite (as a cementing, or coating mineral) is beautifully shown in the SEM photographs.

Hess (1966) summarized natural, experimental, and theoretical considerations to produce a stability diagram for a number of authigenic minerals in the system $\mathrm{K}_{2} \mathrm{O}-\mathrm{Na}_{2} \mathrm{O}-\mathrm{Al}_{2} \mathrm{O}_{3}-\mathrm{SiO}_{2}-\mathrm{H}_{2} \mathrm{O}$ at $25^{\circ} \mathrm{C}$ and 1 atmosphere. Several pertinent isoplethic sections in this system at constant Log $\mathrm{Na} / \mathrm{H}$ are reproduced in Figure 14. Figure $14 \mathrm{~A}$ includes a field defining normal marine conditions. Note on this isopleth that phillipsite and montmorillonite share a boundary, but that K-mica and phillipsite only coexist at a single point, and that with montmorillonite. In more saline conditions, phillipsite and K-mica can coexist without montmorillonite (Figure 14B). In highly saline conditions, the analcime field cuts off phillipsite from K-mica (Figure 14C).

I would therefore interpret the highly saline environment of Figure $14 \mathrm{C}$ as one duplicated by the experiments of Divis and McKenzie, the somewhat hypersaline environment of Figure 14B as one corresponding to conditions at Site 361 during diagenesis of Unit 7, and the normal marine conditions of Figure 14A as one typical of the formation of phillipsite associated with montmorillonite in the deep sea. If authigenic Kfeldspar indeed occurs in the Unit 7 sandstones, then it formed at high $\mathrm{K} / \mathrm{H}$ and $\mathrm{K} / \mathrm{Na}$ as well. In terms of mineral stability, the effect of increasing the salinity appears to be first to expand the phillipsite field into regions of lower silica activity, then to expand the field of analcime into areas of lower silica activity at the expense of montmorillonite and phillipsite. This is in accord with the observations of Hay (1966) on the growth of phillipsite and analcime in saline lakes. Hess's (1966) stability diagram, though, does not take into account the stability of clinoptilolite. The more recent investigations of Stonecipher $(1976 \mathrm{a}, \mathrm{b})$, however, point to an initially siliceous host composition and to the breakdown of smectite to mixed-layer smectite-illite as the most important prerequisites for clinoptilolite formation. The diagenetic transformation of smectite to smectite-illite results in increasing the $\mathrm{Si} / \mathrm{Al}$ ratio of interstitial fluids, and this in turn favors transformation of any initial phillipsite to clinoptilolite. High salinities, however, suppress the stability of montmorillonite, thus shortcutting the reaction necessary to increase silica activity in pore fluids. It may be, as Kastner and Stonecipher (1976a, b) have emphasized, that phillipsite formation depends more on kinetic factors than on equilibrium conditions in the oceans. Keene et al. (1976) were unable to synthesize phillipsite from basalt glass in 

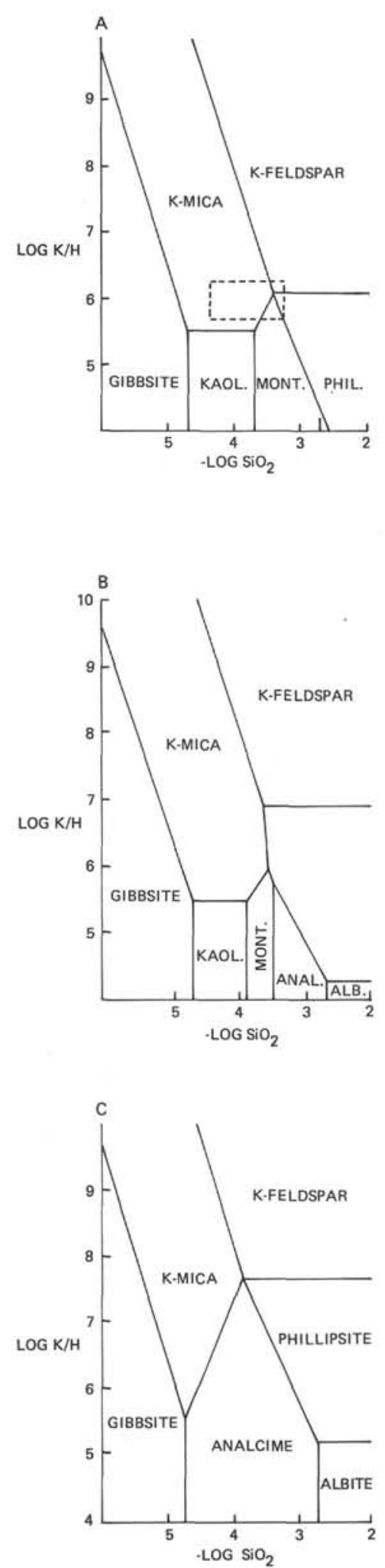

Figure 14. Isoplethic sections of system $\mathrm{K}_{2} \mathrm{O}-\mathrm{Na}_{2} \mathrm{O}-\mathrm{Al}_{2} \mathrm{O}_{3}$ $\mathrm{SiO}_{2}-\mathrm{H}_{2} \mathrm{O}$ at $25^{\circ} \mathrm{C}$ after Hess (1966). (A) Section at $\mathrm{Log}$ $\mathrm{Na} / \mathrm{H}=7.5$. Dotted box corresponds to oceanic environment. $K A O L=$ kaolinite, $M O N T=$ montmorillonite, PHIL = phillipsite. $(B)$ Section at $\log N a / H=8.5$, $K A O L=$ kaolinite, $A N A L=$ analcime. (C) Section at $\mathrm{Log}$ $\mathrm{Na} / \mathrm{H}=9.5, \mathrm{~K}-\mathrm{FELD}=\mathrm{K}$-feldspar PHIL $=$ phillipsite. Sequence shows first increasing stability of phillipsite at the expense of $K$-feldspar and montmorillonite as salinity increases, then increasing stability of analcime at the expense of montmorillonite and phillipsite. The system qualitatively explains the authigenic association $K$-feldspar, illite (K-mica), phillipsite, kaolinite revealed by SEM micrographs in Unit 7 sandstones as the result of heightened salinity (greater Na/H). SEM micrographs (Plates 5 and 6) support the association of phillipsite with K-mica and $K$-feldspar, but not with kaolinite polymorphs.

hydrothermal experiments using normal seawater. Instead, they formed montmorillonite and analcime. Only by spiking seawater with excess $\mathrm{K}$ were they able to synthesize phillipsite. They concluded that only an initial addition of $\mathrm{K}$ to basalt glass by halmyrolysis could provide the necessary abundance of $\mathrm{K}$ to form phillipsite. We have earlier concluded that no substantial modification of $\mathrm{K} / \mathrm{Rb}, \mathrm{K} / \mathrm{Sr}$, or $\mathrm{K} / \mathrm{Ba}$ occurred in Unit 7 sandstones as a result of interaction with seawater, probably because of the high overall rate of sedimentation, and because of the effectively catastrophic deposition of the individual sandstone beds as turbidites and traction flows. The formation of phillipsite, then, depended on the initial high potassium contents of the host sediments, and on the suppression of silica activity by higher salinities of bottom water than prevailed at shallower levels of the Cape Basin at the same time (cf. Site 330 on the Falkland Plateau).

Phillipsite, illite, and kaolinite, but not montmorillonite, also occur in the Late Cretaceous carbonaceous shales of Site 364 (Siesser and Bremner, this volume). But unlike Site 361 , these shales are interbedded with limestones and dolomitized limestones, rather than sandstones. These limestones are barren of even relict calcareous microfossils (see Chapter 3, this volume). Several lines of evidence indicate that here, as well as at Site 361 , highly saline conditions were responsible for the authigenic mineral assemblage in the shales. Most important, of course, is that the shales and limestones overlie the Aptian salt plateau of the Angola Basin. The lower cores of Site 364 must have been very close to the salt, because of high pore water alkalinity and chlorinity in the shales (Sotelo and Gieskes, this volume). Matsumoto et al. (this volume) found that individual dolomite grains in the limestones are high in sodium. They argue that the waters in which the limestones were deposited must have been hypersaline to produce high-Na dolomite. One can argue, perhaps, that these high-Na dolomites reflect diagenesis in the present, or older, highly saline pore waters, and do not reflect the composition of seawater in the Late Cretaceous. However, high-Na dolomite was also found in the Cretaceous limestones of Site 363 on Walvis Ridge, where there is no underlying salt, and where present pore waters are not highly saline (Sotelo and Gieskes, this volume). Matsumoto and co-workers concluded that the Angola Basin was filled with highly saline water when the Site 364 carbonaceous shales were deposited, and that this water mass lapped over the top of Walvis Ridge. 
The Site 364 limestones associated with the carbonaceous shales also might be interpreted as something like the deep-marine evaporite facies of the Red Sea, in which the evaporite mineral gypsum forms in surface waters, settles to the sea floor, and undergoes bacterial reduction leaving unfossiliferous carbonate muds, which later convert to darkened pyritic limestone (Friedman, 1972). In the Red Sea, carbonates formed in this manner consist mostly of low- $\mathrm{Mg}$ calcite, as opposed to the typical high-Mg calcite of most marine carbonates. Dolomitization, which increases downward at Site 364, probably has eliminated this feature of the limestones. The crucial fact, though, is that they are essentially barren of microfossils, and were thus probably bacterial or chemical precipitates, rather than planktonic carbonates.

These lines of evidence thus support hypersaline conditions in the Angola Basin during deposition of the carbonaceous facies:

1) micritic, unfossiliferous limestones predominate;

2) the mineral dolomite is unusually high in $\mathrm{Na}$;

3) the authigenic mineral assemblage in the shales is illite-phillipsite-kaolinite.

4) the carbonaceous facies was deposited immediately above salt; anoxic conditions thus represented only a diminishing, not a cessation, of the conditions which produced the salt.

At Site 361 , we have only the third of these conditions to indicate unusually saline bottom waters. But we know that the basin was filled with anoxic water, and it is thus plausible that it also was unusually saline. In addition, we have somewhat weak, but nevertheless positive evidence from pore water chemistry (Sotelo and Gieskes, this volume), that the Cape Basin carbonaceous facies followed the formation of evaporites by an unknown amount of time, and with an unknown sequence of intervening lithologies.

Carbonaceous sediments at Sites 361 and 364 contain abundant framboidal pyrite (Noël and Melguen, this volume). In a synthesis of experimental work and observations of marine sediments, Sweeney and Kaplan (1973) suggested that pyrite framboid formation was inhibited in sediments at low $\mathrm{pH}$, inasmuch as Farrand (1970) produced experimental framboidal pyrite at a $p \mathrm{H}$ of 8 . This may be a confirmation that diagenesis in these carbonaceous sediments occurred at high $p \mathrm{H}$, as suggested by the saline lake analogy for the formation of phillipsite.

Noël and Melguen (this volume) also report on the abundance of casts of nannofossils in Unit 7 shales, shales which have little or no $\mathrm{CaCO}_{3}$. Beautifully preserved details of the former calcareous material can be seen in the impressions they have left in the soft carbonaceous clays, but the calcite has been entirely dissolved. Kastner et al. (in press) offer an explanation for the role of carbonate in the diagenesis of siliceous oozes, which I use here. It so happens that in more typical marine sediments, carbonate accelerates diagenesis of opaline silica to quartz, whereas clays inhibit it. The crucial fact is that clays compete with opal for pore water alkalinity, whereas carbonate provides no such competition. Calcium carbonate equilibrates with water by a well-known series of reactions resulting in solution of a small amount of carbonate and bicarbonate ions. Hydroxyl is also produced. Formation of clays from feldspars and other minerals requires a large supply of various cations, especially $\mathrm{K}^{+}$, and of hydroxyl. In rapidly deposited sediments, where diagenesis occurs in a "sealed-off" environment in which seawater does not provide an effectively infinite supply either of cations or of hydroxyl, formation of clays and zeolites would tap all available sources of cations and hydroxyl. Thus, though the equilibrium constants of calcite in seawater may have been low, the small amount of hydroxyl produced would have been quickly taken up by clays, forcing more $\mathrm{CaCO}_{3}$ into solution. Calcium and magnesium would also have been taken up, though not as effectively as $\mathrm{K}$ and $\mathrm{Na}$. The result would have been almost complete dissolution of carbonate microfossils during diagenesis. Maintenance of critical levels of alkalinity in pore solutions thus was the principal mechanism of solution of calcium carbonate in the Unit 7 shales. Only rarely were microfossils preserved. Apparently, $\mathrm{Ca}^{+2}$ was heavily concentrated in pore solutions because it was not readily accommodated in either clays or zeolites. It tended to migrate from the shales in which most of the original $\mathrm{CaCO}_{3}$ was deposited as nannofossils, into the porous sandstones, where diagenetic clay formation was minimal, and forced the precipitation of massive $\mathrm{CaCO}_{3}$ cement (Plate 3, Figure 1). Even today, calcium is so highly concentrated in pore waters (Sotelo and Gieskes, this volume), that several months after the Site 361 cores were brought up, gypsum formed on the sawed surfaces of drying carbonaceous shale samples. The buffering of $\mathrm{Ca}^{+2}$ in the pore fluids thus undoubtedly involved organic compounds and sulfides, not simply the composition of the original pore fluids (slightly hypersaline seawater) and authigenic silicates.

If, as is indicated by Figures $14 \mathrm{~B}$ and $14 \mathrm{C}$, montmorillonite stability is suppressed at high salinities, a ready mechanism exists for formation of dolomite associated with carbonaceous shales at Site 364. Formation both of authigenic pyrite and of the association illite-phillipsite should promote the transformation of detrital montmorillonite, or of smectiteillite, to illite. Bacterial reduction of sulfate requires a source of iron such as montmorillonite (see Figure 6) to form pyrite, and breakdown of montmorillonite would be necessary to maintain the pore fluid silica activity needed to compensate its alkalinity. The result would be breakdown of montmorillonite with release of $\mathrm{Mg}$ (see Figure 6) to solution. The Mg could reasonably be expected to wind up in dolomite. The Site 364 dolomites are unusually high in $\mathrm{Na}$ and $\mathrm{Fe}$ as well (Matsumoto et al., this volume), consistent with the mechanism proposed here, that breakdown of montmorillonite under hypersaline conditions provides $\mathrm{Fe}$ as well as $\mathrm{Mg}$. Siesser and Bremner (this volume) report no montmorillonite in the Site 364 carbonaceous shales, although it is abundant in other units of Site 
364. There appears to be no reason why it should not originally have been a component of the Site 364 shales (although it clearly was not a significant original component in Unit 7 of Site 361), and it is therefore plausible to ascribe its absence now to a result of diagenesis, specifically formation of dolomite in adjacent limestone beds, and pyrite in the shales.

\section{CIRCULATION OF THE SOUTH ATLANTIC DURING THE CRETACEOUS}

Up to this point, we have only discussed the circulation of the South Atlantic during the Cretaceous in piecemeal fashion, as bits and pieces of evidence from sedimentary structures or compositions, or from paleontology, have been developed. When we consider the problem of circulation in its own right, the following picture emerges.

During most of the Cretaceous, the newly opened basins of the South Atlantic were supplied ocean water from only one direction, the south (Premoli-Silva and Boersma, 1977; Scheibnerova, this volume; Beckmann, this volume; Ryan and Bolli, this volume; Chapters 2-4, this volume). A connection to the North Atlantic did not exist until what is now the Amazon coast of Brazil separated from the great land mass of northern Africa in the Late Cretaceous (Francheteau and Le Pichon, 1973). Thus apart from one narrow channel of water stretching to cold, high southern latitudes, the northern reaches of the South Atlantic:were entirely landlocked, in most directions for thousands of miles. This paper has demonstrated that little rain fell in the high-latitude regions that were the sources for Unit 7 sediments, and it was decidedly more arid in the warmer north (Morgan, this volume). As if this were not enough, a major volcanic constriction, the Walvis Ridge and São Paulo Ridge, straddled the Mid-Atlantic Ridge at about the midpoint of the narrow seaway (Figure 1; see Chapter 3, this volume). The result was almost complete isolation of the Angola and Brazil basins from the Cape and Argentine basins. At times, the crest of the volcanic ridge may have been entirely above sea level, cutting the northern basins off entirely from their source of seawater. Thus during the Early Cretaceous, at best only small amounts of seawater passed north of the constriction through narrow sills. And in the arid climate, these waters evaporated leaving extensive salt deposits. Drilling on DSDP Legs 39 and 40 was not able to establish whether the basins north of the Walvis Ridge-Rio Grande Rise complex were ever completely desiccated in a manner similar to the Mediterranean (Ryan, Hsü, et al., 1973), or whether a constant supply of water was available to immerse shallow shelves, tidal flats, and sabkhas where the evaporites precipitated. But up to 2000 meters of evaporites accumulated and underlie the continental margins of both Brazil and Angola (Pautot et al., 1973; Asmus and Ponte, 1973).

The southern end of the narrow seaway was also constricted. The Falkland Plateau did not move past the tip of southern Africa until the Albian (Barker, Dalziel, et al., 1977) and Aptian carbonaceous shales overlie shallow-water and subaerial deposits at Site 330
(Thompson, 1977). Seawater only had access to the South Atlantic by way of a tortuous pathway along the Agulhas Fracture Zone (Francheteau and Le Pichon, 1973; Dingle and Scrutton, 1974). At this time, while the Angola and Brazil basins were accumulating salts, an anoxic water mass persisted in the Cape and Argentine basins for at least 5 million years (the duration of the Aptian).

There are at least two factual reasons and one logical reason why the water mass in the Cape Basin was density stratified during the Aptian, and why, for example, an oxygen-minimum layer was not responsible for the carbonaceous sediments in Unit 7. First of all, Unit 7 was deposited on oceanic basaltic basement in the deepest part of the Cape Basin (Chapter 2, this volume). Secondly, the authigenic mineral assemblage required unusually saline, and therefore dense, bottom water conditions, as discussed in the previous section. The third reason, the "logical" one, stems from a consideration of how an anoxic water mass can have persisted in a basin for such a long time, at least the duration of the Aptian, or about 5 million years. To develop this argument properly requires a short digression into "modern" analogs for the type of restricted basin the South Atlantic was during the Cretaceous.

Probably the closest modern parallel to the double, virtually landlocked, linked ocean basins of the South Atlantic is the Mediterranean Sea, with its two major basins, the eastern Ionian Basin, and the western Balearic Basin, separated from each other and from the Atlantic Ocean by very shallow sills. In these basins, Tertiary evaporites and euxinic facies have been deposited in complex patterns, the former involving the apparently complete desiccation of the sea (Ryan, Hsu, et al., 1973). In the present-day Mediterranean, current patterns are well understood (Wüst, 1961). Evaporation exceeds precipitation over the Ionian Basin, causing surface waters to become dense and sink. These spill over the narrow sill between Sicily and North Africa and are replaced by surface counterflow from the Balearic Basin. A dense tongue of water flowing west from the Ionian Basin eventually spills over the Straits of Gibraltar into the Atlantic, where it forms an important intermediate water mass. This spillover is counterbalanced by surface water inflow from the Atlantic. The counterflow plus the input of rivers and rainfall matches the combined effects of evaporation and dense-water outflow from the Mediterranean.

The Mediterranean, however, differs tectonically from the Cretaceous South Atlantic in being a sea between two continental masses, Africa and Eurasia, which have come closer together since the Cretaceous. It has been periodically closed and opened to both the Atlantic and Indian oceans, and by and large, has had a much more complex history than the South Atlantic. An important difference is that the Mediterranean lacks a feature of potentially major importance for the thermohaline circulation of nearly enclosed basins-an active oceanic spreading center. The Red Sea is a better analog of the early South Atlantic basins in this respect, although it is only one basin constricted at its southern end, the narrow straits of Bab El Mandeb. Fresh, iron- 
and titanium-rich basalts of the oceanic tholeiite suite have been dredged from the axial trough of the Red Sea (Chase, 1969) where high heat flow has warmed dense, hypersaline, and metal-rich brines to over $40^{\circ} \mathrm{C}$ (Ross, 1969), and sediments to over $60^{\circ} \mathrm{C}$ (Erickson and Simmons, 1969). The high evaporation has resulted in dense, saline waters below the 150-meter sill depth (Siedler, 1969). These waters have fairly uniform temperature and salinity to the depth of the brine pools (over $2000 \mathrm{~m}$ ) in which both increase sharply. Low density Indian Ocean waters flow into the Red Sea to replace those lost by surface evaporation. At the north end of the Red Sea, evaporation renders the surface waters dense enough to sink and add to the waters trapped behind the sill. Their sinking forces spillage of the trapped waters over the sill into the Gulf of Aden. Although there are no hydrographic data to support it, there must be an expansion (volume increase) of bottom water due to geothermal heating that adds to this spillage and accelerates surface-water counterflow.

The mean renewal time of Red Sea waters is 20 years (Siedler, 1969). Most of this circulation occurs in the upper 150 meters, which by itself has a renewal time of close to 6 years. Renewal times of the deeper waters are therefore considerably more than 20 years, and may be several hundred years. The deep waters have been dated by radiocarbon techniques at about 200 years (Craig, 1969). With these turnover rates, most of the Red Sea is oxygenated, the exception being the brines. The surface waters thus become dense enough and are supplied rapidly enough to carry oxygen virtually to the bottom of the Red Sea, preventing deeper waters from becoming generally anoxic. To maintain large anoxic basins in the young South Atlantic for several million years, then, required either relatively lower surfacewater evaporation rates, or a layer of deeper water dense enough to prevent sinking surface waters from reaching any significant depth.

The waters spilling from the Red Sea into the Gulf of Aden are as much as $6^{\circ} \mathrm{C}$ warmer than the waters they enter $\left(22^{\circ} \mathrm{C}\right.$ versus $\left.16^{\circ} \mathrm{C}\right)$, yet they are so dense that they sink to the deepest levels of the Gulf (Siedler,1969). During the Cretaceous, the basins of the South Atlantic arc thought to have been arrayed in their present northsouth configuration, but possibly to have been as much as $20^{\circ}$ further south (Francheteau and Le Pichon, 1973; Dingle and Scrutton, 1974). The north end of the South Atlantic therefore was in the tropics and the south end at cool-temperate latitudes. This is confirmed by the occurrence of a boreal calcareous microfossil assemblage throughout the Cretaceous at Site 361 in the Cape Basin, and a temperate to tropical assemblage at Site 364 in the Angola Basin (Bolli, this volume; Beckmann, this volume). Similar relationships are evident from palynomorphs (MacLachlan and Pieterse, this volume; Morgan, this volume). In fact, tropical and semi-arid conditions are indicated at Site 364 during the Late Cretaceous (Morgan, this volume). These climatic inferences suggest that waters of the Angola-Brazil Basin should have been considerably warmer, more saline, and denser than waters of the Cape-Argentine Basin during the Cretaceous. Circulation patterns may have behaved in a manner similar to that between the Red Sea and Gulf of Aden today.

The effects of geothermal heating of bottom waters near ridge crests have only recently been appreciated. The deep thermohaline circulation of the modern oceans, of course, mainly involves the movements of cold bottom waters from high latitudes. Geothermal effects at ridge crests in the Pacific, Atlantic, and Indian oceans are principally those of heating, and perhaps diminishing the flow of these bottom currents. In restricted basins, however, geothermal heating of bottom water can have dramatic consequences. The Panama Basin is one such modern restricted basin. It is triangular in shape, bounded on the northwest by Cocos Ridge, the southwest and south by Carnegie Ridge, and the east by South America. The central portion of the basin is occupied by the Galapagos Spreading Center (Raff, 1968; Lonsdale and Klitgord, in press). Bottom water is heated along the ridge crest (Detrick et al., 1974) and leaves the basin by slow, diffuse flow over the surrounding ridges (Lonsdale, in press). The dramatic hydrographic and geologic effects center on the waters taken into the Panama Basin to replace the outflow. Hagen and Lonsdale (1976) and Lonsdale (1977, in press) report extremely strong inflow $(33 \mathrm{~cm} / \mathrm{sec})$ along the principal deep-water break in the enclosing ridges, the Ecuador trench between the Carnegie Ridge and Ecuador. Here, in spite of high sedimentation rates, the trench axis is swept free of sediments. The inflow water is cold, deep water that traveled from high southern latitudes to the Peru Basin via gaps in the East Pacific and Chile rises (Lonsdale, in press). The deep water is literally siphoned into the Panama Basin by the outflow, but its entry is constricted almost entirely to the narrow gap at the trench. At 2930 meters, the sill depth is over 1000 meters shallower than the regional sea-floor depth south of Carnegie Ridge, and the depth of the trench on the north side of the constriction. The siphoning effect pulls the water up and over the sill, where it pours down a type of spillway into the Panama Basin. The inflow waters, of course, insure a steady supply of oxygen to the deep waters of the Panama Basin. The residence time of bottom water in the Panama Basin has been calculated to be less than 50 years (Lonsdale, in press), a consequence of circulation induced entirely by geothermal heating of waters at the Galapagos Spreading Center. It is evident that in enclosed basins containing active spreading centers, geothermally driven circulation alone can be sufficient to prevent them from becoming anoxic provided the circumstances are right. In the case of the Panama Basin, it is evidently very important that the Ecuador trench sill, constricted though it is, is also quite deep, virtually as deep as the mean depth of the Panama Basin.

For geometric and climatic reasons, it seems likely that the circulation of the Cretaceous South Atlantic was similar to the Red Sea and Mediterranean circulation patterns of today. This conclusion was also reached by McCoy and Zimmerman (1977). Yet as we have seen from the examples of the Panama Basin and 
Red Sea, high sills and density stratification alone are not sufficient to insure anoxic conditions in a small ocean basin. Three factors would have mitigated against a Red Sea-type circulation so vigorous that it would have oxygenated the deep Cape Basin.

1) High surface productivity: This would have insured that surface waters made dense enough to sink by evaporation were also oxygen depleted. This links one aspect of oxygen-minimum models to density stratification models.

2) Large basin size: Given a fixed rate of heating of bottom water along the Mid-Atlantic Ridge, and climatic stability, a large basin would have allowed longer residence times for bottom waters than a small basin. The Cape and Argentine basins during the Aptian were much wider and on the average deeper than the Red Sea is today. Even if the rate of spillout from the Cape Basin to the Indian Ocean was the same as the rate from the Red Sea to the Gulf of Aden today, the larger volume of water trapped behind the Agulhas sill would have taken longer to cycle out than Red Sea deep waters. This would both enhance the likelihood of having anoxic deep waters, and would insure their stability against short-term surface-water productivity fluctuations affecting the supply of oxygen-depleted waters.

3) High bottom-water density: No matter how vigorous thermohaline circulation might have become, if the anoxic water mass was denser than any potential oxygenating water mass, it would not have overturned. In the restricted South Atlantic, with its wide latitude range, the most likely way to have made dense water was by evaporation in the hot, arid north, increasing its salinity. The dense water could have spilled from the Angola evaporite basin into the Cape Basin, or it could have formed by a high rate of evaporation of surface waters at the north end of the Cape Basin. Either situation would have seen dense, saline waters sinking to the deeper parts of the Cape Basin. Some of these might have been similar to Red Sea brines in being too dense to mix with other waters, even though greatly heated at the spreading axis. The presence of phillipsite among Unit 7 authigenic minerals is evidence for such dense, unusually saline bottom waters in the Cape Basin.

It is possible that the Walvis Ridge-São Paulo Plateau obstruction was the stabilizing factor in preventing large volumes of dense hypersaline water from flushing the anoxic waters from the Cape Basin, and setting up a true Red Sea-type situation where vigorous thermohaline circulation kept deep waters oxygenated. Simultaneously, by trapping most of the dense waters in the Angola and Brazil basins, evaporite formation was enhanced. The Cape Basin reciprocated geochemically by depleting surface waters entering the Angola Basin in both carbon and sulfur (now seen as organic matter and pyrite in Unit 7 of Site 361). This inhibited the formation of both carbonate and gypsum, deferring the precipitation of calcium until late stages of evaporite deposition, when unusual volumes of calcium chloride minerals such as tachyhydrite formed (Wardlaw and Nicholls, 1972).

The crucial pillar upon which all this rests is that a high sill was absolutely required at the Agulhas
Fracture Zone. Deepening of this sill would have set up a Panama Basin-type circulation in which cold oxygenated high latitude Indian Ocean waters could have been siphoned into the Cape Basin in response to geothermal heating of seawater in the Cape Basin. This indeed is what I propose happened in the Albian, when the Cape Basin finally became oxygenated.

The development of circulation in the South Atlantic during the Cretaceous is shown schematically on Figure 15. The situation just described for the Aptian is shown in Figure 15A, that for the onset of oxygenating conditions in the Cape Basin during the Albian is shown in Figure 15B. At this time, there is no reason to infer a major climatic change. Therefore, the major thermohaline circulation should still have been dominated by a high rate of evaporation in the Angola Basin. The Site 364 Albian dolomite-carbonaceous shale sequence may well represent the final stages of evaporite deposition, as discussed in the previous section. Consequently, water spilling from the Angola Basin to the Cape Basin was analogous to water leaving the Ionian Basin for the Balearic Basin in the Mediterranean today. At various times in the Late Cretaceous, the water spilling over Walvis Ridge may have been dominantly anoxic, especially during times when carbonaceous shales were deposited at Site 364-in the Albian and again in Turonian-Coniacian times. These correspond to the times of peak erosion and deposition of contourites at Site 363 on Walvis Ridge (see Plate 2, Column 3 and Chapter 3), and with deposition of a small amount of carbonaceous material in Cores 22-24 and 27 of Unit 6 of Site 361. Both the composition and pollen assemblage of Unit 6 sediments indicates a more northern provenance than Unit 7. This and sedimentary structures in Unit 6 are consistent with a southward-flowing contour-following current of dense water spilling from the Angola Basin into the Cape Basin, as discussed earlier. Because it was flowing southward in the Southern Hemisphere, the Coriolis effect would have intensified this current to the east, against the margin of southwestern Africa. Two situations are depicted on Figure 15, one (15B) showing the situation when both Angola Basin and Cape Basin deep waters were oxygenated (e.g., late Albian or postConiacian times), the other (15C) when anoxic waters spilled from the Angola Basin, across Walvis Ridge and the Orange River delta, bringing with it organic matter and sediments from this area.

Shortly after the breakup of anoxic conditions in the Angola Basin in the Late Cretaceous, current activity over Walvis Ridge sharply dropped, and only pelagic clays (not laminated siltstones) were deposited at Site 361 (Unit 5). The deepening of all sills, including the sill between the South and North Atlantic, allowed freer circulation of surface and deep waters between oceans. The southward-flowing contour-following undercurrent in the Cape Basin probably became less dense, and either ceased to exist, or moved to a shallower density level.

\section{ACKNOWLEDGMENTS}

I would like to thank W.B.F. Ryan, Peter Lonsdale, J.B. Keene, and Sharon Stonecipher for much interesting discussion and many helpful comments on the various aspects 


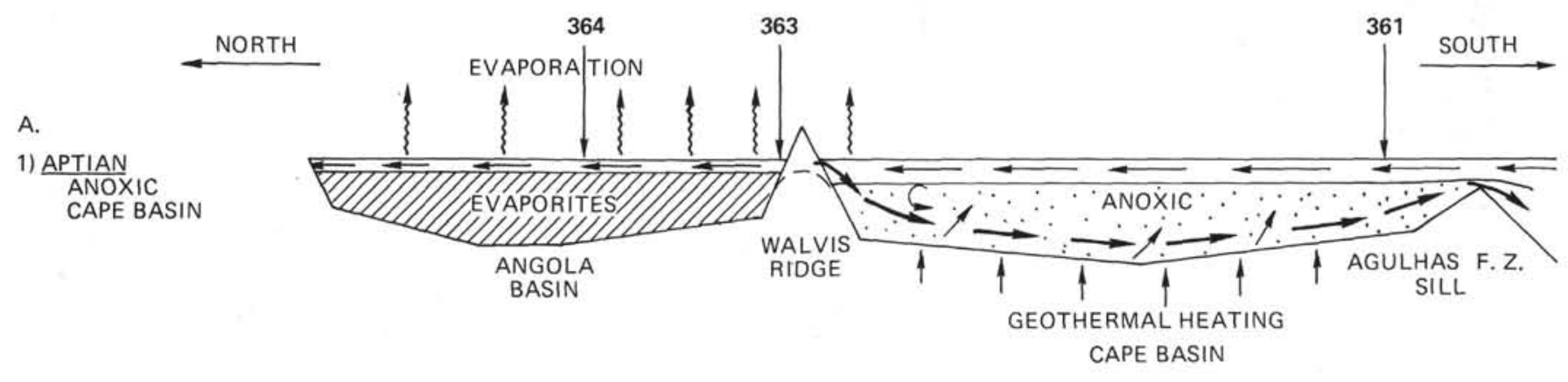

B.

2) ALBIAN ANOXIC ANGOLA BASIN

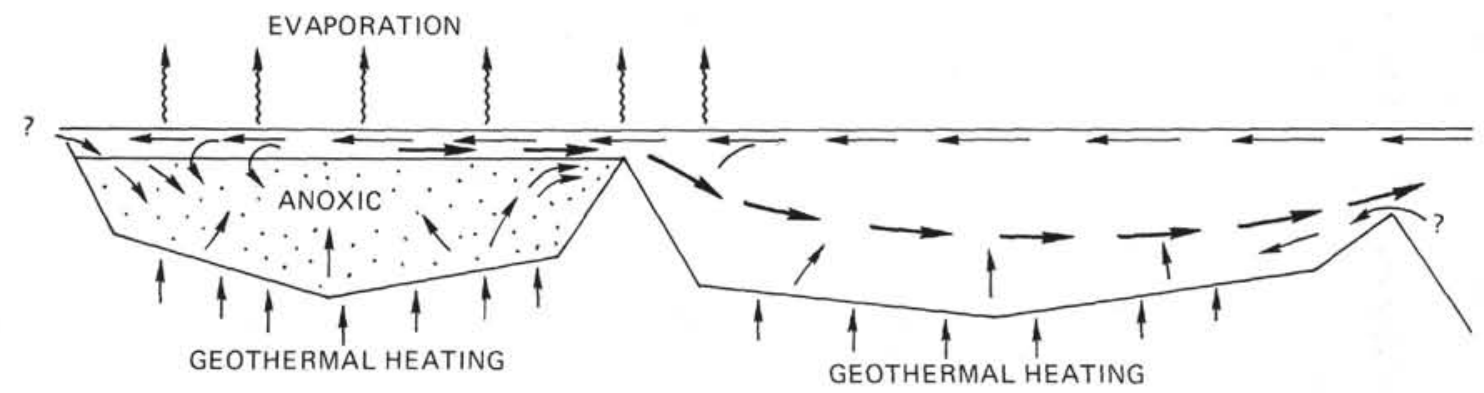

c.

3) TURONIAN OVERTURN OF ANOXIC WATERS FROM THE ANGOLA TO THE CAPE BASIN

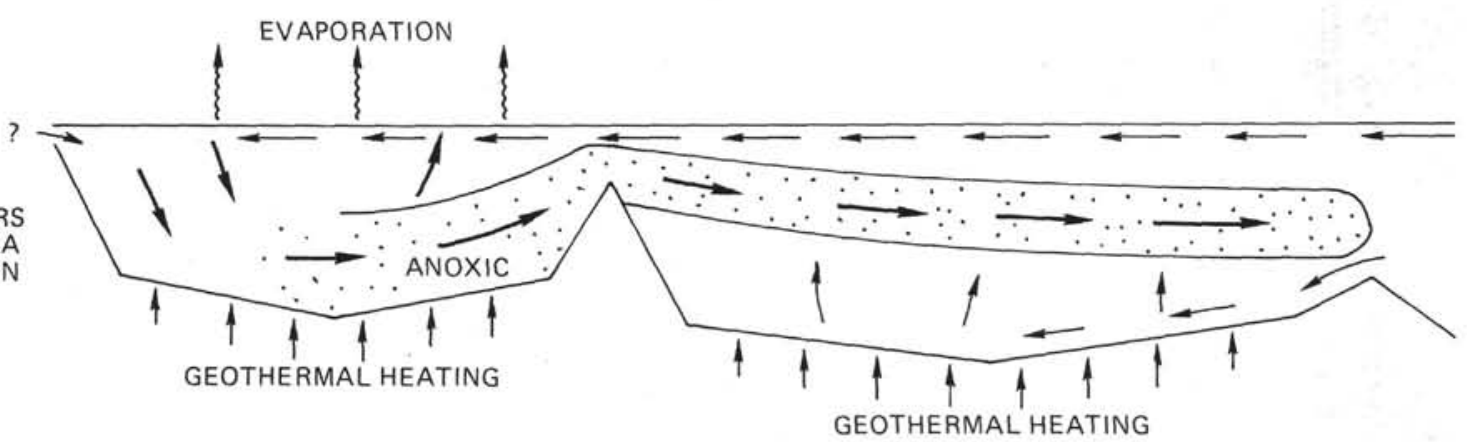

SCHEMATIC THERMOHALINE

CIRCULATION IN THE SOUTH ATLANTIC

DURING THE CRETACEOUS

Figure 15. (A) Stage 1, Aptian: Evaporite deposition in Angola-Brazil Basin. Sapropel deposition in Cape-Argentine Basin. Heating of bottom waters in the Cape-Argentine Basin along the Mid-Atlantic Ridge with resultant spillage along Agulhas Fracture Zone sill into southern Indian Ocean, and exchange with oxygenated surface and intermediate waters. AngolaBrazil Basin may periodically have dried out completely but if not bottom waters here also probably rose in response to heating along the Mid-Atlantic Ridge, and spilled into the Cape-Argentine Basin to be replaced by surface counterflow. (B) Stage 2, Albian: Angola-Brazil Basin anoxic; Cape-Argentine Basin oxygenated. Heating along both segments of ridge crest as before. Cold water counterflow replaced heated waters. Counterflow began in southern Indian Ocean and reached both basins. Some counterflow may have come from the North Atlantic. Counterflow waters not significantly denser than anoxic waters of Angola-Brazil Basin. (C) Stage 3, Santonian: Last episode of flushing of anoxic waters from Angola Basin. May have been a response to sinking of unusually dense waters (a response to even drier climate than usual?), or to unusually dense (cold) oxygenated counterflow waters from Cape-Argentine Basin, or to tectonic-magmatic events deepening sills along the Walvis Ridge-São Paulo Plateau complex.

of this paper. Carol Edgerton took the SEM photographs, and Richard Meyers, Rob Dunbar, and Carolyn Nelson helped with the analytical work. Cost for the latter was defrayed by DSDP Science Activities Funds allocated to Leg 40 post-cruise work.

\section{REFERENCES}

Allsopp, H.L. and Kolbe, P., 1965. Isotopic age determinations on the Cape Granite and intruded 1048
Malmesbury sediments, Cape Peninsula, South Africa: Geochim. Cosmochim. Acta, v. 29, p. 1115-1130.

Arrhenius, G., 1963. Pelagic sediments. In Hill, M.N. (Ed.), The Sea: New York (Interscience), p. 655-718.

Arthur, M.A., 1976. The oxygen minimum expansion, intensification and relation to climate (Abstract). Joint Oceanographic Assembly, Edinburgh, 12-24 September 1976.

Asmus, H.E. and Ponte, F.C., 1973. The Brazilian Marginal Basins. In Nairn, A. E. M. and Stehli, F. G. (Eds.), The 
ocean basins and margins. Volume I. The South Atlantic: New York (Plenum), p. 87-134.

Barker, P., Dalziel, I.W.D., et al., 1977. Initial Reports of the Deep Sea Drilling Project, Volume 36: Washington (U.S. Government Printing Office).

Beydoun, Z.R., 1970. Southern Arabia and northern Somalia: comparative geology: Phil. Trans. Roy. Soc. London, Series A, v. 267, p. 267-292.

Bolli, H.M., Ryan, W.B.F., et al., 1975. Basins and margins of the eastern South Atlantic: Geotimes, v. 20, p. 22-24.

Boström, K., Joensuu, O., Valdes, S., and Riera, M., 1972. Geochemical history of South Atlantic Ocean sediments since Late Cretaceous: Mar. Geol., v. 12, p. 85-121.

Bouma, A.H., 1962. Sedimentology of some flysch deposits: Amsterdam (Elsevier Publishing Co.).

Boyce, R.E. and Bode, G.W., 1970. Carbon and carbonate analyses, Leg 9. In Hays, J. D. et al., Initial Reports of the Deep Sea Drilling Project, Volume 9: Washington (U.S. Government Printing Office), p. 797-816.

Chase, R.L., 1969. Basalt from the axial troughs of the Red Sea. In Degens, E. and Ross, D. (Eds.), Hot brines and Recent heavy metal deposits in the Red Sea: New York (Springer-Verlag), p. 122-130.

Clark, F.W., 1924. Data of geochemistry: U.S. Geol. Surv. Bull. 770 .

Craig, H., 1969. Geochemistry and origin of the Red Sea brines. In Degens, E. and Ross, D. (Eds.), Hot brines and Recent heavy metal deposits in the Red Sea: New York (Springer-Verlag), p. 208.

Dalrymple, G.B. and Clague, D.A., 1976. Age of the Hawaiian-Emperor Bend: Earth. Planet. Sci. Lett., v. 31, p. 313-329.

Daly, R.A., 1933. Igneous rocks and the depths of the earth: New York (Hafner reprint, 1968).

Deer, W.A., Howie, R.A., and Zussman, J., 1962. Rockforming minerals, Volume 3 (sheet silicates). New York (John Wiley \& Sons, Inc.).

Detrick, R.S., Williams, D.L., Mudie, J.D., and Sclater, J.G., 1974. Bottom water temperatures at the Galapagos Spreading Center: Geophys. J. Roy. Astron. Soc., v. 38, p. $627-637$.

DeVore, G.W., 1957. The surface chemistry of feldspars as an influence on their decomposition products: Clays Clay Minerals, v. 6, p. 26-41.

Dingle, R.V. and Scrutton, R.A., 1974. Continental breakup and the development of post-Paleozoic sedimentary basins around southern Africa: Geol. Soc. Am. Bull., v. 85, p. 1467-1474.

Divis, A.F. and McKenzie, J.A., 1975. Experimental authigenesis of phyllosilicates from feldspathic sands: Sedimentology, v. 22, p. 147-155.

Emery, K. O., Uchupi, E., Brown, C. O., Philips, J., and Simpson, E.S.W., 1975. Continental margin off western Africa: Cape St. Francis (South Africa) to Walvis Ridge (South-West Africa): Am. Assoc. Petrol. Geol. Bull., v. 59 , p. $3-59$.

Engel, A.E.J., Engel, C.G., and Havens, R.G., 1965. Chemical characteristics of oceanic basalts and the upper mantle: Geol. Soc. Am. Bull., v. 76, p. 719-734.

Erickson, A.J. and Simmons, G., 1969. Thermal measurements in the Red Sea hot brine pools. In Degens, E. and Ross, D. (Eds.), Hot brines and Recent heavy metal deposits in the Red Sea: New York (Springer-Verlag), p. 114-121.

Farrand, M., 1970. Framboidal sulphides precipitated synthetically: Mineralium Deposita, v. 5, p. 237-247.
Francheteau, J. and Le Pichon, X., 1972. Marginal fracture zones as structural framework of continental margins in South Atlantic Ocean: Am. Assoc. Petrol. Geol. Bull., v. 56 , p. 991-1007.

Franks, S. and Nairn, A.E.M., 1973. The equatorial marginal basins of West Africa. In Nairn, A.E.M. and Stehli, F.G. (Eds.), The ocean basins and margins, Volume 1. The South Atlantic: New York (Plenum Press), p. 301-346.

Friedman, G.M., 1972. Significance of Red Sea in problem of evaporites and basinal limestones: Am. Assoc. Petrol. Geol. Bull., v. 56, p. 1072-1086.

Gass, I.G., 1970. The evolution of volcanism in the junction area of the Red Sea, Gulf of Aden, and Ethiopian rifts: Phil. Trans. Roy. Soc. London, Series A, v. 267, p. 369 381 .

Goldberg, E.D., 1957. Biogeochemistry of trace metals. In Hedgepeth, J.W. (Ed.), Treatise on marine ecology and paleoecology: Geol. Soc. Am. Mem. 67, p. 345-358.

Grim, R.E., 1968. Clay Mineralogy: New York (McGrawHill).

Hagen, R. and Lonsdale, P., 1976. Inflow of bottom water to the Panama Basin (Abstract): E.O.S. Am. Geophys. Union Trans., v. 57, p. 260.

Haughton, S.H., 1969. Geological history of Southern Africa: Johannesburg (Geol. Soc. S. Africa).

Hay, R.L., 1966. Zeolites and zeolitic reactions in sedimentary rocks: Geol. Soc. Am. Spec. Paper 85, p. 1-129.

Hess, P. C., 1966. Phase equilibria of some minerals in the $\mathrm{K}_{2} \mathrm{O}-\mathrm{Na}{ }_{2} \mathrm{O}-\mathrm{Al}_{2} \mathrm{O}_{3}-\mathrm{SiO}_{2}-\mathrm{H}_{2} \mathrm{O}$ system at $25^{\circ} \mathrm{C}$ and 1 atm.: Am. J. Sci., v. 264, p. 289-309.

Hollister, C. and Heezen, B., 1973. Geological effects of bottom currents, western North Atlantic. In Gordon, A.L. (Ed.), Studies in physical oceanography, a tribute to Georg Wust on his 80th birthday, v. 2: New York (Gordon and Breach), p. 15-39.

Hughes, N.F., 1973. Palynological time-correlation of English Wealden, with boreal marine successions. In Casey, R. and Rowson, P.F. (Eds.), The Boreal Lower Cretaceous: Geol. J. Spec. Issue no. 5: Liverpool (Seal House Press), p. 185-192.

Kastner, M. and Stonecipher, S.A., 1976. Zeolites in pelagic sediments of the Atlantic, Pacific and Indian oceans: International Zeolite Conf., Tucson, Arizona.

Kastner, M., Keene, J.B., and Gieskes, J.M., in press. Diagenesis of siliceous oozes I. Chemical controls on the rate of Opal-A diagenesis, and experimental study.

Keene, J.B., Clague, D.A., and Nishimori, R.K., 1976. Experimental hydrothermal alteration of tholeitic basalt: resultant mineralogy and textures: J. Sediment. Petrol., v. 46 , p. $647-653$.

Kolbe, P., 1966. Geochemical investigation of the Cape Granite, south-western Cape Province, South Africa: Geol. Soc. S. Africa. Trans., v. 69, p. 161-199.

Kröner, A., 1974. The Gariep Group Part I. Late Precambrian formations in the western Richtersveld, northern Cape Province, Univ. of Cape Town, Chamb. Mines Precamb. Res. Group Bull. 13.

Larson, R.L. and Ladd, J.W., 1973. Evidence for the opening of the South Atlantic in the Early Cretaceous: Nature, v. 246 , p. $209-212$.

Larson, R.L., Moberly, R., et al., 1975. Initial Reports of the Deep Sea Drilling Project, Volume 32: Washington (U.S. Government Printing Office).

Lonsdale, P., in press. Inflow of bottom water to the Panama Basin: Deep-Sea Res.

Lonsdale, P. and Klitgord, K.D., in press. Structure and tectonic history of the eastern Panama Basin: Geol. Soc. Am. Bull. 
Margolis, S.V., 1968. Electron microscopy of chemical solution and mechanical abrasion features on quartz sand grains: Sediment. Geol., v. 2, p. 243-256.

Martin, H., Mathias, M., and Simpson, E.S.W., 1960. The Damaraland subvolcanic ring complexes in South-West Africa: Rept. 21st, Int. Geol. Congr. pt. 13, p. 156-174.

MCoy, F. W., and Zimmerman, H. B., 1977. A history of sediment lithofacies in the South Atlantic Ocean. In PerchNielsen, K. and Supko, P., et al., Initial Reports of the Deep Sea Drilling Project, Volume 39: Washington (U. S. Government Printing Office), p. 1047-1079.

Nicolaysen, L., 1962. Stratigraphic interpretation of age measurements in southern Africa. In Engel, A.E.J., James, H.L., and Leonard, B.F. (Eds.), Petrologic studies: A volume in honor of A.F. Buddington: Geol. Soc. Am., p. 569-598.

Pautot, G., Renard, V., Daniel, J., and Dupont, J., 1973. Morphology, limits, origin, and age of salt layer along South Atlantic African margin: Am. Assoc. Petrol. Geol. Bull., v. 57, p. 1658-1672.

Pettijohn, F. J., 1975. Sedimentary Rocks (3rd Edition), New York (Harper and Row), 628 p.

Pettijohn, F.J., Potter, P.E., and Siever, R., 1972. Sand and sandstone: New York (Springer-Verlag).

Premoli-Silva, I. and Boersma, A., 1977. Cretaceous planktonic foraminifers-DSDP Leg 39 (South Atlantic). In Perch-Nielsen, K. and Supko, P., Initial Reports of the Deep Sea Drilling Project, Volume 39: Washington (U. S. Government Printing Office), p. 615-642.

Poldervaart, A., 1966. Archean charnockitic adamellite phacoliths in the Keimoes-Kakamas region, Cape Province, South Africa; Geol. Soc. S. Afr. Trans., v. 69, p. 139-154.

Raff, A.D., 1968. Sea-floor spreading-another rift: J. Geophys. Res., v. 73, p. 3699-3705.

Ross, D.A., 1969. Temperature structure of the Red Sea brines. In Degens, E. and Ross, D.A. (Eds.), Hot brines and Recent heavy metal deposits in the Red Sea: New York (Springer-Verlag), p. 148-152.

Ryan, W.B.F., Hsu, K.J., et al., 1973. Initial Reports of the Deep Sea Drilling Project, Volume 13: Washington (U.S. Government Printing Office).

Schlanger, S.O., Jackson, E.D., et al., 1976. Initial Reports of the Deep Sea Drilling Project, Volume 33: Washington (U.S. Government Printing Office).
Scholtz, D.L., 1946. On the younger Pre-Cambrian plutons of the Cape Province: Geol. Soc. S. Africa Proc., v. 49, p. 35-82.

Shaw, D. M., 1968. A review of K-Rb fractionation trends by covariance analysis. Geochim. et Cosmochim. Acta, v. 32, p. 573-601.

Siedler, G., 1969. General circulation of water masses in the Red Sea. In Degens, E. and Ross, D.A. (Eds.), Hot brines and Recent heavy metal deposits in the Red Sea: New York (Springer-Verlag), p. 131-138.

Siedner, G. and Miller, G.A., 1968. K-Ar age determinations on basaltic rocks from South-West Africa and their bearing on continental drift: Earth Planet. Sci. Lett., v. 4, p. 451 .

Stonecipher, S.A., 1976a. Chemistry of deep-sea phillipsite, clinoptilolite, and host sediments: Internat'l Zeolite Conf. Tucson, Arizona.

1976b. Origin, distribution, and diagenesis of phillipsite and clinoptilolite in deep-sea sediments: Chem. Geol., v. 17, p. 307-318.

Sweeney, R. E. and Kaplan, I. R., 1973. Pyrite framboid formation: laboratory synthesis and marine sediments: Econ. Geol., v. 68, p. 618-634.

Tankard, A.J. and Krinsley, D.H., 1974. Diagenetic surface textures on quartz grains: an application of scanning electron microscopy: Geol. Soc. S. Africa Trans., v. 77, p. $285-290$.

Thompson, R.W., 1977. Mesozoic sedimentation on the eastern Falkland Plateau. In Barker, P., Dalziel, I.W.D., et al., Initial Reports of the Deep Sea Drilling Project, Volume 36: Washington (U.S. Government Printing Office), p. 877-892.

Sliter, W.V., 1977. Cretaceous foraminifers from the southwestern Atlantic Ocean. In Barker, P.F., Dalziel, I.W.D., et al., Initial Reports of the Deep Sea Drilling Project, Volume 36: Washington (U.S. Government Printing Office), p. 519-574.

Vine, J.D. and Tourtelot, E.R., 1970. Geochemistry of black shale depposits-a summary report: Econ. Geol., v. 65, p. 253-272.

Wardlaw, N. C. and Nicholls, G. D., 1972. Cretaceous evaporites of Brazil and West Africa and their bearing on the theory of continental separation. Proc. Int. Geol. Congr., 24th Sess., Sect. 6, p. 43-44.

Wuist, G., 1961. On the vertical circulation of the Mediterranean Sea: J. Geophys. Res., v. 66, p. 3261-3271. 



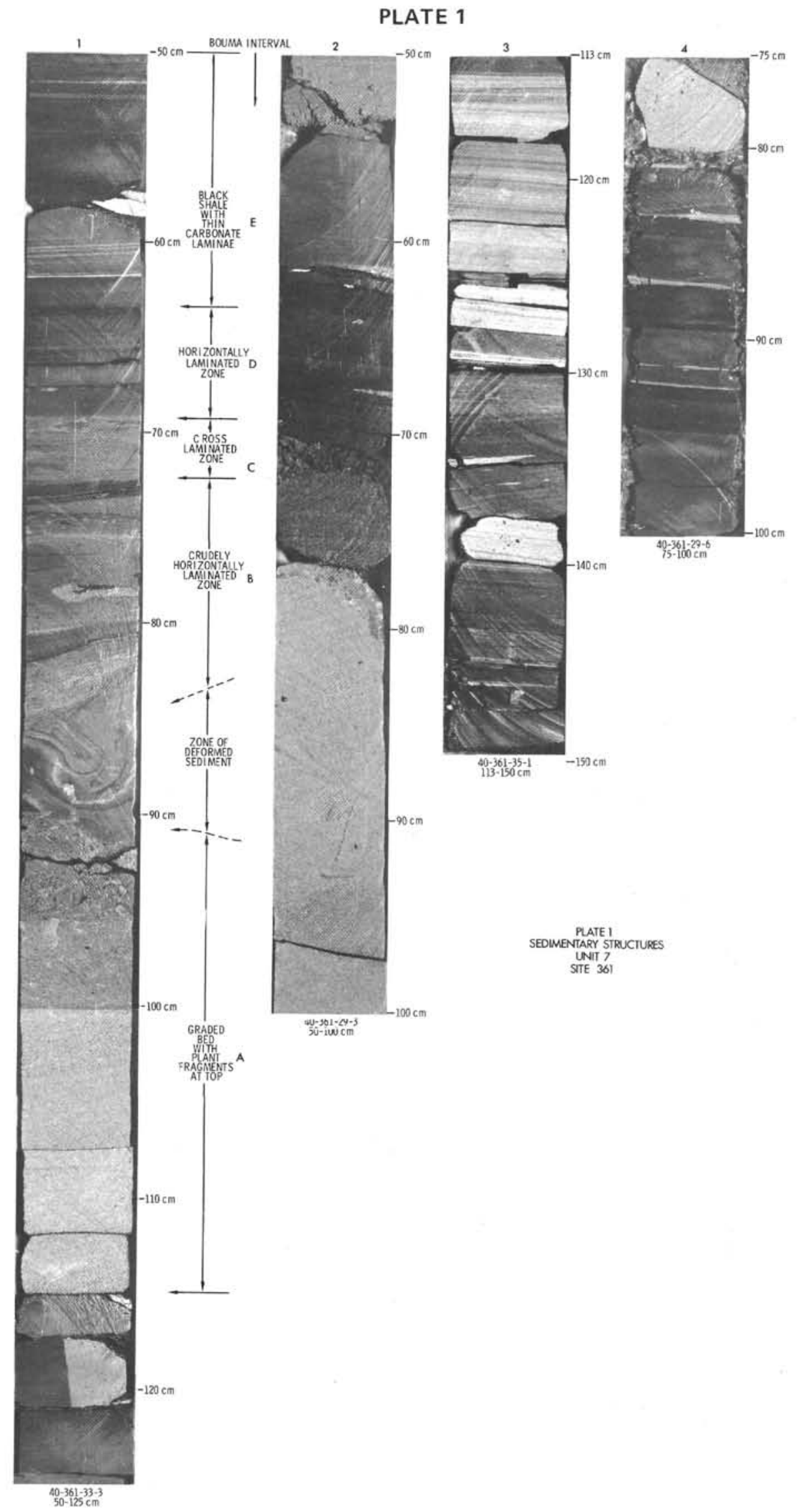


PLATE 2
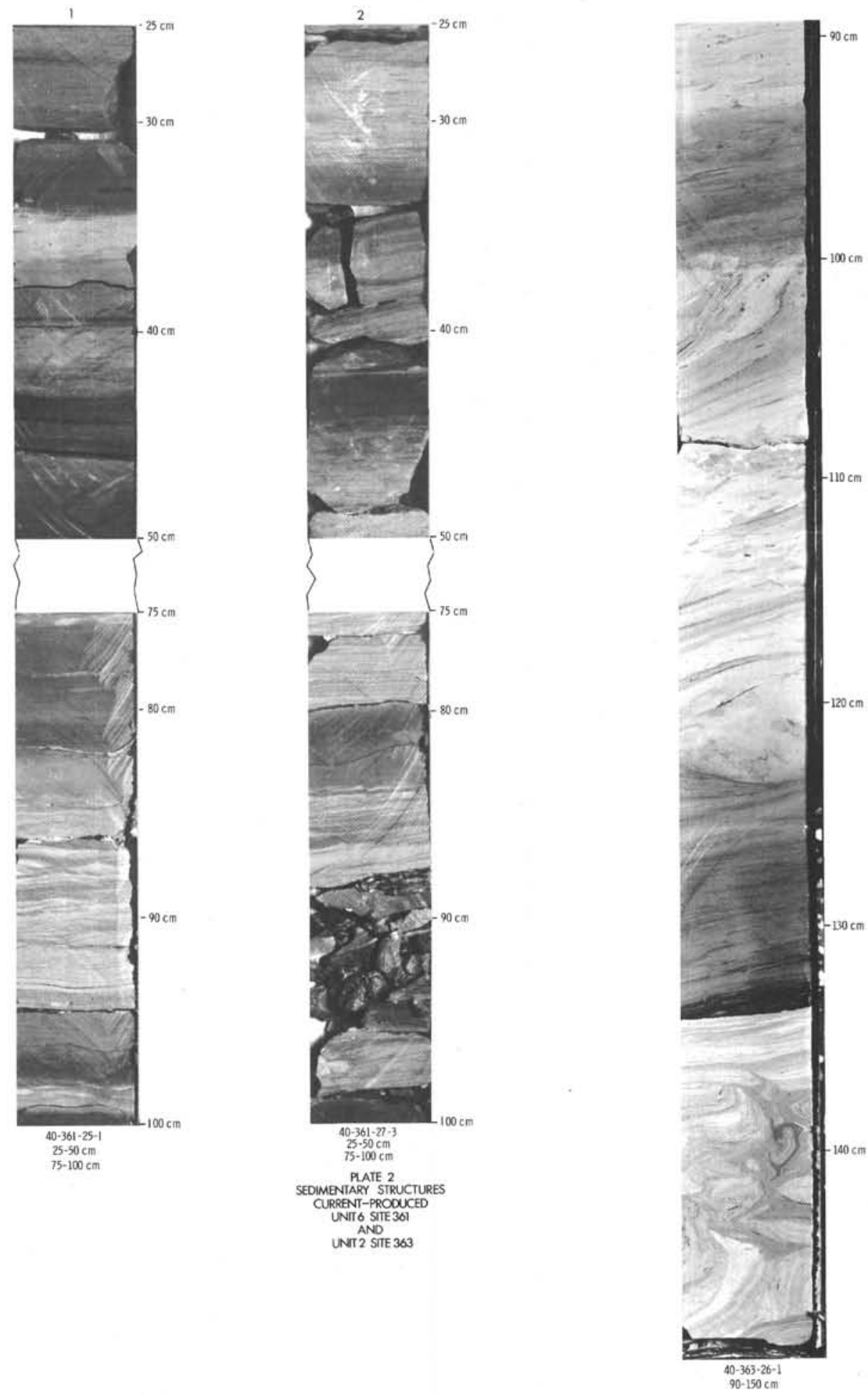


\section{PLATE 3}

Petrography of Unit 7 Sandstones

Figure 1 Photomicrograph of quartz and shale grains cemented by calcite, crossed nichols. Sample 40361-45-1, 128-130 cm, Unit 7 sandstone.

Figure 2 Photomicrograph of rounded shale grain in sandstone, plane light. Sample 40-361-28-2, 4-8 $\mathrm{cm}$, Unit 7 sandstone.

Figure 3 Photomicrograph of shale grain showing bedding, crossed nichols. Sample 40-361-48-1, 102-104 cm, Unit 7 sandstone.

Figure 4 Photomicrograph of shale grain showing bedding and an inner concentric "zone" of carbonaceous matter, plane light. Sample 40-361-45-1, 128-130 $\mathrm{cm}$ Unit 7 sandstone.

Figure 5 Photomicrograph of angular quartz grain in claycemented sandstone, crossed nichols. Sample 40361-43-4, 97-100 cm, Unit 7 sandstone. 
PLATE 3
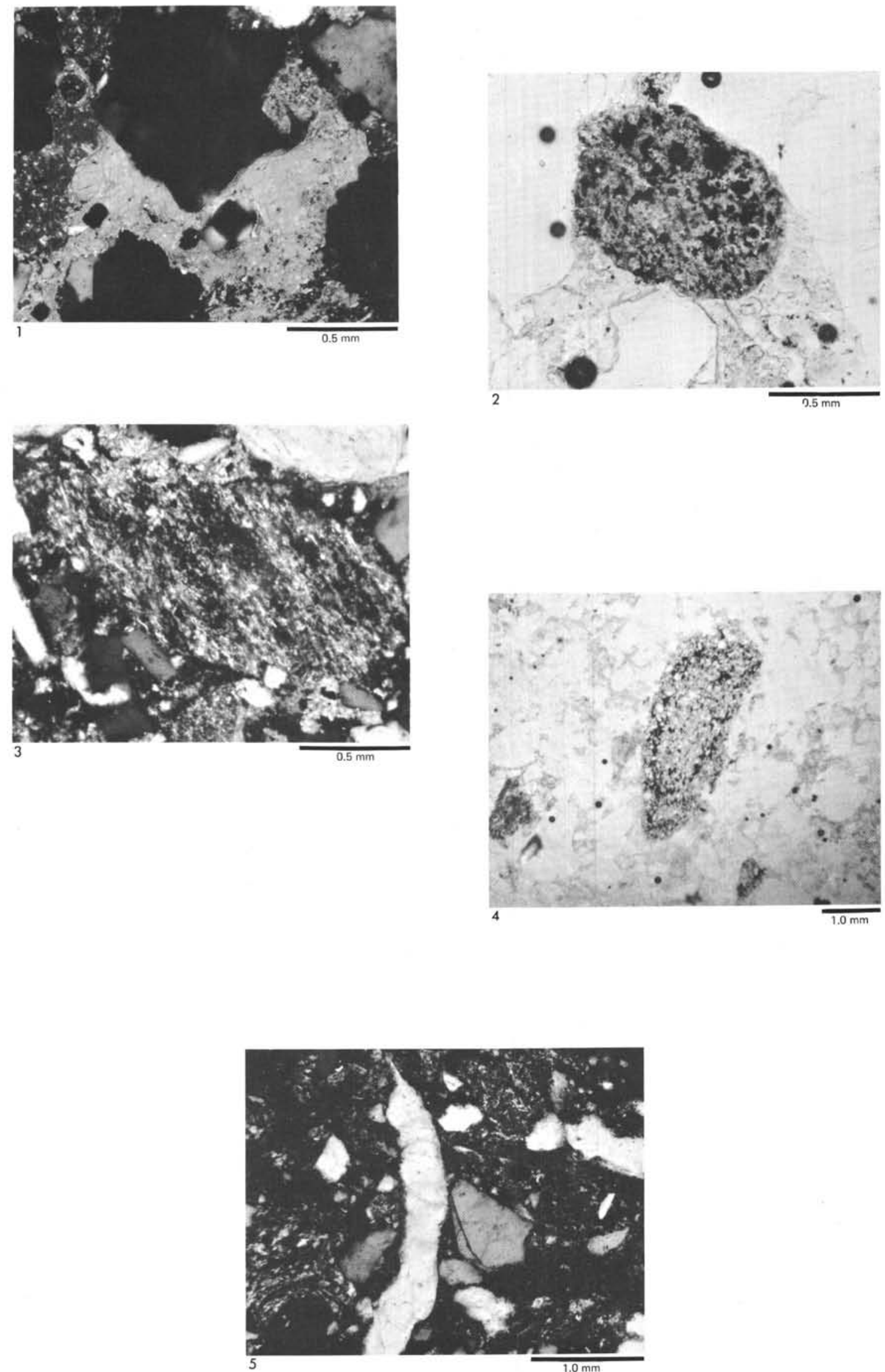


\section{PLATE 4}

Carbonaceous Matter and Pyrite in Unit 7 Sandstones (See color photographs in Frontispiece)

Figure $1 \quad$ Framboidal pyrite cluster in calcite-cemented sandstone, reflected light. Sample 40-361-48-1, 25$29 \mathrm{~cm}$, Unit 7 sandstone.

Figure 2 Same as Figure 1, only in transmitted light.

Figure 3 Framboidal pyrite associated with cellular plant material, reflected light. Sample 40-361-45-2, 114$117 \mathrm{~cm}$, Unit 7 sandstone.

Figure 4 Mat of fine carbonaceous matter between grains in sandstone, transmitted light. Sample 40-361-29-3, $77-81 \mathrm{~cm}$, Unit 7 sandstone.

Figure 5 Same as Figure 4, only in reflected light, revealing fine granular pyrite in center of mat of organic material.

Figure 6 Another example of pyrite, some framboidal, associated with amorphous organic material, reflected light. Sample 40-361-43-3, 68-70 cm. 
PLATE 4
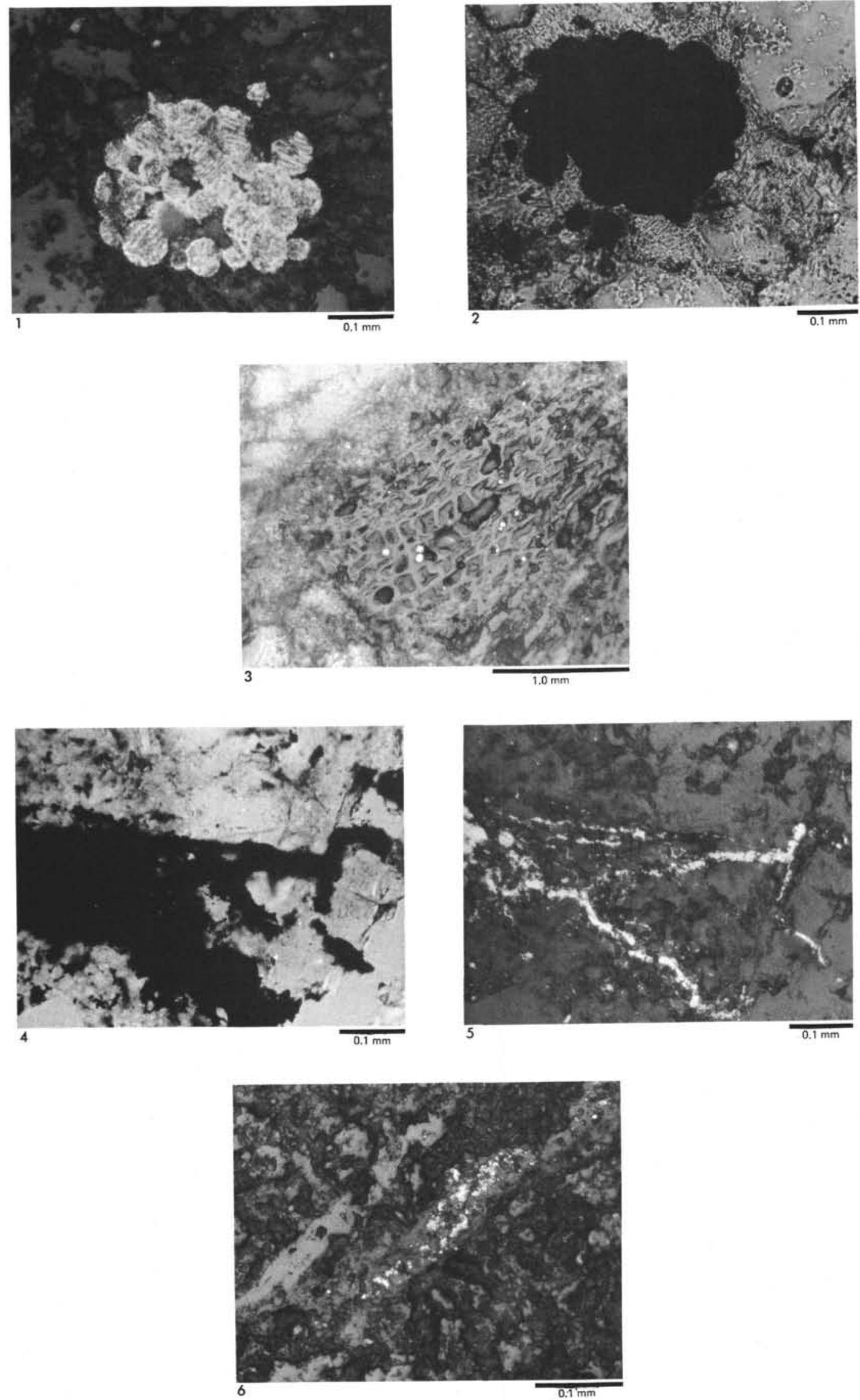


\section{PLATE 5}

Scanning Electron Micrographs of Dissolution Features in Sand Grains and cemented clumps from Site 361 Unit 7 Sandstones

Figure 1 Etch pits on quartz crystal faces of quartzite grain, tending to form orthogonal notches along cleavage planes.

Figure 2 Dickite bundle broken from a clump of cemented $\mathrm{K}$-feldspar and quartz. Quartz grain to left has strongly etched surface preferentially concentrated along cleavage planes in the extreme upper-left corner, and shows a notch-like etch pattern, minor flaking, and some reprecipitation on the rest of the exposed surface (orthogonal to upper left surface). Quartz grain to upper right has faint, subparallel dissolution grooves on flatter surface, dissolution fluting and Riecke solution pit on cross-cutting crystallographic surfaces. Grain at lower right is coated with clays through which a blocky crystal and a doubly terminated crystal, both probably phillipsite, can be seen.

Figure 3 Strongly etched surface of quartz grain, typical of quartz grains in sandstones of Unit 7, with fragments on verge of flaking from surface.

Figure 4 Crystallographically controlled etching on Kfeldspar grain, showing lattice control on the development of kaolinite plates. The clay-coated stub in the center was apparently protected from dissolution by its coating of clays (illite).

Figures 5,6 Growth of dickite polymorph of kaolinite in etch pits in $\mathrm{K}$-feldspar grains. Figure 5 shows close crystallographic control of feldspar lattice on development of clays, whereas Figure 6 shows a similar dickite bundle deeply embedded in a spectacular solution cavity.

Figure $7 \quad$ Plagioclase grain parting along clay-coated cleavage surfaces. 
PLATE 5
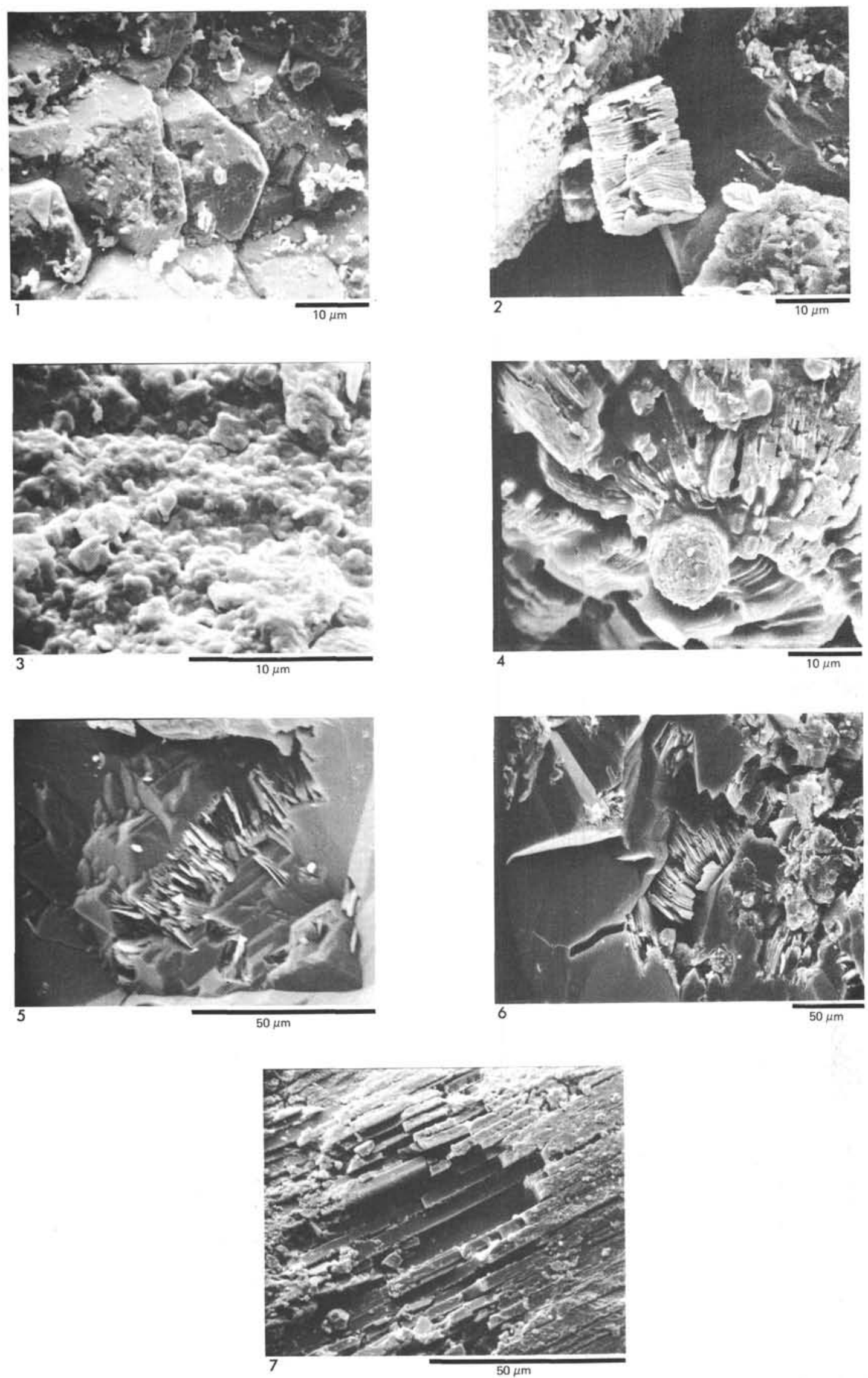


\section{PLATE 6}

Scanning Electron Micrographs of Authigenic Minerals in cemented clumps from Unit 7 Sandstones, Site 361

Figure $1 \quad$ Flaky illite plates coating quartz grain. Upper surface of quartz grain is fracture surface.

Figure 2 Plates of illite coating quartz grain.

Figure 3 Detail of clay-coated stub in K-feldspar grain of Plate 5 Figure 4 . Clays have platy structure similar to clays in Figure 2.

Figure 4 Possible phillipsite or authigenic K-feldspar crystals, one viewed sideways (center), the other end-on (lower left, double-domed termination visible), on surface of quartz grain. The quartz grain and crystals have been thinly coated with fine, amorphous clays.

Figure 5 Halloysite polymorph of kaolinite growing from poorly-structured platelike clays coating a wood fragment. The platelike clays probably contain organic material in their structure. A common association of halloysite is organic material (Grim, 1964).

Figure $6 \quad$ Halloysite showing curvature of individual tubes. Both Figures 5 and 6 show the tendency of halloysite to grow in subparallel sprays. In the central portions of these sprays, the stacking of clays is probably very similar to that of dickite, the other polymorph of kaolinite. The tubes may actually have begun growing dendritically from a dickite-type structure. 


\section{PLATE 6}
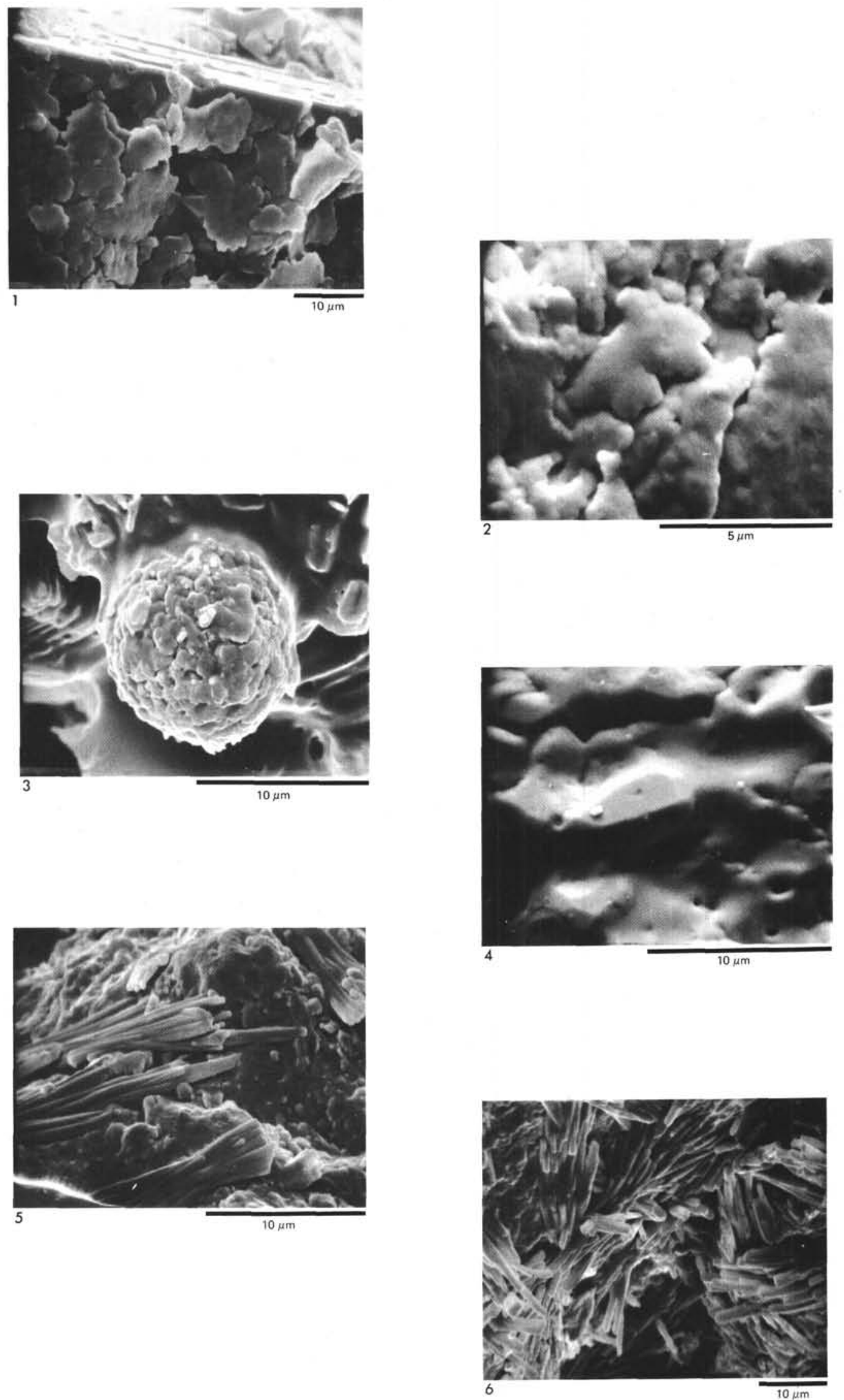